\title{
POLISH BIBLIOGRAPHY OF OCCUPATIONAL MEDICINE, 2011
}

\section{GRAŻYNA KOWALCZYK}

Nofer Institute of Occupational Medicine, Łódź, Poland

Department of Knowledge Management

\section{ASSESSMENT OF OCCUPATIONAL HYGIENE}

1. Aniołczyk H, Mariańska M, Mamrot P. Optimization of methods for measurement and assessment of occupational exposure to electromagnetic fields in physiotherapy (SW diathermy). Med Pr 2011;62(5):499-515, 27 ref. [in Polish].

2. Bieńkowski P, Zubrzak B, Surma R. Electromagnetic field of the mobile phone base station: case study. Med Pr 2011;62(1):37-45, 11 ref. [in Polish].

3. Brochocka A, Pietrowski P. The onfluence of catalyst coating on carbon materials - safe use of gas filters for organic vapours. Bezpiecz Pr 2011;(6):27-9, 9 ref. [in Polish].

4. Brzeźnicki S, Bonczarowska M, Gromiec J. 1,4-Butynediol - A determination method. Podst Met Oceny Srod Pr 2011;27(1):51-7 [in Polish].

5. Brzeźnicki S, Bonczarowska M, Gromiec J. p-Toluidine - $A$ determination method. Podst Met Oceny Srod Pr 2011;27(1):155-160 [in Polish].

6. Bujak-Pietrek S, Mikołajczyk U, Szadkowska-Stańczyk I. Dust concentration analysis in non-coal mining. Exposure evaluation based on measurements performed by occupational hygiene laboratories in the years 2001-2005 in Poland. Med Pr 2011;62(2):113-25, 25 ref. [in Polish].

7. Domański W. Benzene, cyclohexane, ethylbenzene, n-hexane, methylcyclohexane, toluene - A determination method. Podst Met Oceny Srod Pr 2011;27(1):35-44 [in Polish].
8. Gawęda E. Beryllium and its compounds - A determination method. Podst Met Oceny Srod Pr 2011;27(1):45-9 [in Polish].

9. Gawęda E. Copper and its compounds - A determination method. Podst Met Oceny Srod Pr 2011;27(1): 149-53 [in Polish].

10. Gawęda E. New methods of signifying chemical substances (4). Bezpiecz Pr 2011;(11):27-9, 8 ref. [in Polish].

11. Harkawy A, Górny RL, Ogierman L, Wlazło A, Ławniczek-Wałczyk A, Niesler A. Bioaerosol assessment in naturally ventilated historical library building with restricted personnel access. Ann Agric Environ Med 2011;18(2):323-9, 58 ref.

12. Hellgren UM, Hyvarinen M, Holopainen R, Reijula K. Perceived indoor air quality, air-related symptoms and ventilation in Finnish hospitals. Int J Occup Med Environ Health 2011;24(1):48-56, 20 ref. DOI: 10.2478/ s13382-011-0011-5.

13. Jankowska E. Investigation of welders' exposure to particles present in welding fumes. Bezpiecz Pr 2011;(9): 7-9, 8 ref. [in Polish].

14. Jeżewska A. Aziridine - A determination method. Podst Met Oceny Srod Pr 2011;27(1):23-7 [in Polish].

15. Jeżewska A. Diacetyl - A determination method. Podst Met Oceny Srod Pr 2011;27(1):79-84 [in Polish].

Received: July 2, 2012. Accepted: July 4, 2012.

Address reprint request to G. Kowalczyk, Department of Scientific Information, Nofer Institute of Occupational Medicine, św. Teresy 8, 91-348 Łódź, Poland (e-mail: kogra@imp.lodz.pl). 
16. Jeżewska A. 2-Methylaziridine - A determination method. Podst Met Oceny Srod Pr 2011;27(1):143-7 [in Polish].

17. Jeżewska A, Buszewski B. Aniline - A determination method. Podst Met Oceny Srod Pr 2011;27(1):17-22 [in Polish].

18. Jeżewska A, Buszewski B. 4-Chloroaniline - $A$ determination method. Podst Met Oceny Srod Pr 2011;27(1):67-72 [in Polish].

19. Jeżewska A, Buszewski B. 4,4'-Methylenedianiline A determination method. Podst Met Oceny Srod Pr 2011;27(1):137-42 [in Polish].

20. Kalwasiński D, Filipek D. Multimedia visualization of mechanical hazards connected with using machinery in the metal industry. Bezpiecz Pr 2011;(11):14-7, 9 ref. [in Polish].

21. Kondej D, Gawęda E. Metal concentrations in dust fractions emitted at industrial workplaces. Podst Met Oceny Srod Pr 2011;27(1):5-15, 42 ref. [in Polish].

22. Kondej D, Gawęda E. Determining metals in dust fractions - A determination method. Podst Met Oceny Srod $\operatorname{Pr}$ 2011;27(1):129-35 [in Polish].

23. Kowalska J. Ethyl 2-cyanoacrylate - A determination method. Podst Met Oceny Srod Pr 2011;27(1):73-8 [in Polish].

24. Kowalska J, Zapór L. Assessing exposure to biological and chemical agents in small eateries. Bezpiecz Pr 2011;(5):12-5, 6 ref. [in Polish].

25. Krogulski A, Szczotko M. Microbiological quality of hospital indoor air. Determinant factors for microbial concentration in air of operating theatres. Rocz Panstw Zakl Hig 2011;62(1):109-13, 5 ref. [in Polish].

26. Krzemińska S. Resistance of protective materials to chemical substances - research methodology. Bezpiecz Pr 2011;(7-8):32-4, 8 ref. [in Polish].

27. Kucharska M, Wesołowski W, Gromiec J. Benzoyl chloride - A determination method. Podst Met Oceny Srod Pr 2011;27(1):59-66 [in Polish].
28. Kucharska M, Wesołowski W, Gromiec J. 1,1,2-Trichloroethane - A determination method. Podst Met Oceny Srod Pr 2011;27(1):161-7 [in Polish].

29. Kupczewska-Dobecka M, Czerczak S, Jakubowski M. Evaluation of the TRA ECETOC model for inhalation workplace exposure to different organic solvents for selected process categories. Int J Occup Med Environ Health 2011;24(2):208-17, 8 ref. DOI: 10.2478/s13382011-0021-3.

30. Kurczewska A. Protective anti-electrostatic clothing - requirements. Bezpiecz Pr 2011;(2):12-5, 18 ref. [in Polish]. 31. Łężak K. Interaction of hot welding particles with protective clothing for welders - A new research method. Bezpiecz $\operatorname{Pr}$ 2011;(12):14-6, 10 ref. [in Polish].

32. Machnik G, Pelc E, Zapała M, Gąsecka-Czapla M, Kaczmarczyk G, Kozłowska D, et al. Designing and optimization of real-time RT-PCR technique for the detection of hepatitis $C$ virus (HCV) genome in blood serum as internal laboratory quality control. Przegl Epidemiol 2011;65(2):325-32, 25 ref. [in Polish].

33. Morzyński L. Using genetic algorithms to limit occupational exposure to noise. Bezpiecz Pr 2011;(10): 9-12, 11 ref. [in Polish].

34. Owczarek G, Wolska A, Bartkowiak G. Effectiveness evaluation and choice of barrier fabrics used for protective clothing against ultraviolet radiation. Bezpiecz Pr 2011;(9):18-21, 5 ref. [in Polish].

35. Pachocki KA, Wieprzowski K, Różycki Z, Bekas M, Latour T. Natural radioactivity of potassium 40K in curative and natural mineral waters and dose estimation. Rocz Panstw Zakl Hig 2011;62(1):19-25, 16 ref. [in Polish].

36. Papierz S, Kacprzyk J, Kamiński Z, Adamowicz M, Zmyślony M. Occupational exposure to X and gamma rays in Poland in 2010. Med Pr 2011;62(6): 579-82, 5 ref. [in Polish].

37. Smagowska B. Ultrasonic noise at workstations with machinery and devices with air compression. Bezpiecz Pr 2011;(7-8):38-41, 13 ref. [in Polish]. 
38. Stanisławska M, Janasik B, Trzcinka-Ochocka M. Assessment of occupational exposure of welders based on determination of fumes and their components produced during stainless steel welding. Med Pr 2011;62(4): 359-68, 16 ref. [in Polish].

39. Surgiewicz J. Barium and its soluble compounds A determination method. Podst Met Oceny Srod Pr 2011;27(1):29-34, 2 ref. [in Polish].

40. Surgiewicz J. Aluminium and its compounds $A$ determination method. Podst Met Oceny Srod Pr 2011;27(1):115-21, 2 ref. [in Polish].

41. Surgiewicz J. Cadmium and its compounds - A determination method. Podst Met Oceny Srod Pr 2011;27(1):123-8 [in Polish].

42. Szczerbiński R, Karczewski J. The estimation of intake of selected and permissible preservatives used in food industry among people from Podlaskie voivodeship. Rocz Panstw Zakl Hig 2011;62(1):33-6, 14 ref. [in Polish].

43. Vohra MS. Personal formaldehyde exposure level in the gross anatomy dissecting room at College of Medicine King Saud University Riyadh. Int J Occup Med Environ Health 2011;24(1):108-13, 13 ref. DOI: 10.2478/ s13382-011-0004-4.

44. Wesołowski W, Kucharska M, Gromiec J. 1,2-Dibromoethane - A determination method. Podst Met Oceny Srod Pr 2011;27(1):85-91 [in Polish].

45. Wesołowski W, Kucharska M, Gromiec J. Diethylene glycol dimethyl ether - A determination method. Podst Met Oceny Srod Pr 2011;27(1):99-105 [in Polish].

46. Wesołowski W, Kucharska M, Gromiec J. Pentabromodiphenyl ethers - A determination method. Podst Met Oceny Srod Pr 2011;27(1):107-14 [in Polish].

47. Więcek E. Health criteria for size-selective aerosol sampling in the working environment. Podst Met Oceny Srod Pr 2011;27(2):5-21, 18 ref. [in Polish].

48. Woźnica A, Jeżewska A. 1,2-Epoxy-3-phenoxypropane - A determination method. Podst Met Oceny Srod Pr 2011;27(1):93-8 [in Polish].
49. Zborowska-Dobosz R, Kuziemski A, Maron M, Bahn D, Owczarek A. Legionella contamination of hospital hot water supply systems in the light of research conducted in 2008-2010 as part of supervision by the Country Sanitary Inspector in Bydgoszcz. Przegl Epidemiol 2011;65(3):441-5, 12 ref. [in Polish].

50. Zradziński P, Roman-Liu D. Protection of the operators of suspended guns for resistance welding against electromagnetic and biomechanical hazards. Bezpiecz Pr 2011;(11):10-3, 10 ref. [in Polish].

\section{EXPERIMENTAL PATHOLOGY}

1. Barańska M, Skrętkowicz J. Genetic polymorphism of xenobiotic metabolizing enzymes in autoimmune connective tissue diseases. Przegl Dermatol 2011;98(6): 512-8, 58 ref. [in Polish].

2. Bellinger DC. Recent studies of lead neurotoxicity in children: old metal, new questions. Med Srod 2011;14(3): 7-12, 48 ref.

3. Biedunkiewicz A. Moulds isolated from the upper sections of the respiratory and alimentary tracts of healthy veterinary medicine students. Med Pr 2011;62(3): 259-67, 30 ref. [in Polish].

4. Brinchmann BC, Bayat M, Brogger T, Muttuvelu DV, Tjonneland A, Sigsgaard T. A possible role of chitin in the pathogenesis of asthma and allergy. Ann Agric Environ Med 2011;18(1):7-12, 41 ref.

5. Bukowska A. Anticarcinogenic role of melatonin - potential mechanisms. Med Pr 2011;62(4):425-34, 67 ref. [in Polish].

6. Czernic A, Bartosz M, Błaszczyk J, Andysz A, BłaszczykSuszyńska J. The influence of CoQ10 on enzymatic antioxidant defence of red blood cells in healthy people. Probl Hig Epidemiol 2011;92(3):632-5, 20 ref. [in Polish].

7. Friedrich M, Goluch-Koniuszy Z, Dolot A, Pilarczyk B. Appreciation of selenium concentration in blood and tissues of male rat as a result of diet ingriedients changes and 
its supplementation with chosen group B vitamins. Rocz Panstw Zakl Hig 2011;62(1):41-6, 20 ref. [in Polish].

8. Gać P, Pawlas K. Blood selenium concentration in various populations of healthy and sick people - review of literature from the years 2005-2010. Med Srod 2011;14(1):93-104, 79 ref. [in Polish].

9. Gajowik A, Radzikowska J, Dobrzyńska M. The influence of bisphenol $A$ and of combined exposure to X-rays and bisphenol $A$ to somatic cells of the bone marrow and liver of mice. Rocz Panstw Zakl Hig 2011;62(4):43944, 37 ref. [in Polish].

10. Gralewicz S, Lutz P, Świercz R, Grzelińska Z, Wiaderna D. Neuroendocrine and behavioral response to amphetamine challenge after exposure to an organophosphorus pesticide. Int J Occup Med Environ Health 2011;24(3):283-91, 38 ref. DOI: 10.2478/ s13382-011-0023-1.

11. Grudziński IP. Safety of medicinal nanoproducts: new areas of toxicological research. Rocz Panstw Zakl Hig 2011;62(3):239-46, 59 ref. [in Polish].

12. Hapunik J, Vichova B, Karbowiak G, Wita I, Bogdaszewski M, Pet'ko B. Wild and farm breeding cervids infections with Anaplasma phagocytophilum. Ann Agric Environ Med 2011;18(1):73-7, 50 ref.

13. Henrykowska G, Lewicka M, Dziedziczak-Buczyńska M, Pacholski K, Buczyński A. Estimate of influence of microwaves emitted by active electrodes used in the diagnostics and electropoint therapy on human organism - in vitro studies. Probl Hig Epidemiol 2011;92(1): 30-4, 15 ref. [in Polish].

14. Jabłoński M. Genetic determinants of the alcohol dependence syndrome: searching for an endophenotype associated with sweet liking in families with alcohol addiction. Ann Acad Med Stetin 2011;57(1):79-87, 35 ref. [in Polish].

15. Jakubowski M, Nowakowska B. Carbon tetrachloride. Documentation. Podst Met Oceny Srod Pr 2011;27(4):119-50, 89 ref. [in Polish].
16. Janasik B, Trzcinka-Ochocka M, Brodzka R. Selenium determination in plasma/serum by inductively coupled plasma mass spectrometry (ICP-MS): Comparison with graphite furnace atomic absorption spectrometry (GFAAS). Med Pr 2011;62(5):489-98, 30 ref. [in Polish].

17. Jankowska A, Bystry K, Czerczak S, Nowakowska B. Trichloroacetic acid. Documentation. Podst Met Oceny Srod Pr 2011;27(3):133-54, 83 ref. [in Polish].

18. Kapka-Skrzypczak L, Krasowska E, Cyranka M, Skrzypczak M. The health effects of using solarium. Zdrow Publiczne 2011;121(2):167-73, 50 ref. [in Polish].

19. Kapka-Skrzypczak L, Niedźwiecka J, Cyranka M, Skrzypczak M, Kruszewski MK. The metabolic syndrome and oxidative stress - possibilities of dietotherapy. Med Srod 2011;14(2):57-63, 33 ref. [in Polish].

20. Kołodziejczyk J, Wojciechowska M, Bartuzi Z, Dziedziczko A. Balance of proteinases and antiproteinases and smoking tobacco. Pneumonol Alergol Pol 2011;79(3):207-14, 45 ref. [in Polish].

21. Konieczko K, Czerczak S, Wagrowska-Koski E. Thionyl chloride. Documentation. Podst Met Oceny Srod $\operatorname{Pr}$ 2011;27(2):43-55, 29 ref. [in Polish].

22. Kozłowska A, Olewińska E, Kowalska-Pawlak A, Pawlas N. Mutagenic and cytotoxic factors in PM10 and PM2.5 fractions in atmosphere in Sosnowiec. Med Srod 2011;14(4):21-33, 59 ref. [in Polish].

23. Kruszewski M, Jagiełło W, Kruszewski A, Kuźmicki S, Kruszewski B, Polczyk M. Changes of absolute strength during test exercises after alcohol consumption. Lek Wojsk 2011;89(2):89-92, 19 ref. [in Polish].

24. Kupczewska-Dobecka M, Wągrowska-Koski E. But2-yne-1,4-diol. Documentation. Podst Met Oceny Srod Pr 2011;27(2):23-42, 46 ref. [in Polish].

25. Kupczewska-Dobecka M, Wagrowska-Koski E. Bis(2methoxyethyl) ether. Documentation. Podst Met Oceny Srod Pr 2011;27(4):43-69, 66 ref. [in Polish].

26. Kuryl T, Debski B, Milczarek M, Bertrandt J, Klos A. Effect of carnitine and microelements (chromium and selenium) 
on fatty acids metabolism in healthy and type 1 diabetic rats. Probl Hig Epidemiol 2011;92(3):583-6, 20 ref.

27. Labudda M. Biochemical mechanisms of neurotoxicity caused by cadmium. Rocz Panstw Zakl Hig 2011;62(4):357-63, 71 ref. [in Polish].

28. Lachowicz E, Gosławski W, Spoz E, Lubiński W. Drug induced ocular disorders. Okulistyka 2011;(4):628, 26 ref. [in Polish].

29. Lemieszek M, Chilosi M, Golec M, Skórska C, Huaux F, Yakoub Y, et al. Mouse model of hypersensitivity pneumonitis after inhalation exposure to different microbial antigens associated with organic dusts. Ann Agric Environ Med 2011;18(1):159-68, 85 ref.

30. Łastowiecka-Moras E, Bugajska J. Natural ultraviolet radiation and preliminary skin aging. Bezpiecz Pr 2011;(6):8-10, 13 ref. [in Polish].

31. Łukaszewicz-Hussain A. Liver and serum glutathione concentration and liver hydrogen peroxide in rats subchronically intoxicated with chlorfenvinphos - organophosphate insecticide. Med Pr 2011;62(1):23-9, 32 ref. [in Polish].

32. Łukaszewicz-Hussain A. The effect of organophosphate pesticides on pancreas. Med Pr 2011;62(5): 543-50, 54 ref. [in Polish].

33. Mercier B, Prost J, Prost M. A well-oxygenated cells environment may help to fight against protein glycation. Int J Occup Med Environ Health 2011;24(1): 102-7, 26 ref. DOI: 10.2478/s13382-011-0005-3.

34. Mickiene R, Bakutis B, Baliukoniene V. Antimicrobial activity of two essential oils. Ann Agric Environ Med 2011;18(1):139-44, 33 ref.

35. Myga-Nowak M, Pacholska-Bogalska J, Kwaśniewski W, Kwaśniewska A, Goździcka-Józefiak A. Proliferation of cells and expression of RARs, RXRs and $H P V$ viral E6 and E7 proteins in cervical cancer cell lines after treatment with ATRA. Ann Agric Environ Med 2011;18(1):145-50, 41 ref.

36. Nieradko-Iwanicka B, Borzęcki A. Effect of lambdacyhalothrin on memory and movement in mice after transient incomplete cerebral ischemia. Ann Agric Environ Med 2011;18(1):41-5, 34 ref.

37. Pakulska D, Czerczak S, Wagrowska-Koski E. Sulfuric acid (VI). Documentation. Podst Met Oceny Srod Pr 2011;27(3):95-132, 114 ref. [in Polish].

38. Pakulska D, Czerczak S, Nowakowska B. 1-Methyl2-pyrrolidone. Documentation. Podst Met Oceny Srod Pr 2011;27(4):71-95, 83 ref. [in Polish].

39. Pałaszewska-Tkacz A, Czerczak S, Wągrowska-Koski E. 4-Aminotoluene (p-toluidine). Documentation. Podst Met Oceny Srod Pr 2011;27(2):169-86, 27 ref. [in Polish].

40. Pałaszewska-Tkacz A, Czerczak S, Wagrowska-Koski E. Benzene-1,2,4-tricarboxylic acid 1,2-anhydride. Documentation. Podst Met Oceny Srod Pr 2011;27(3): 5-29, 62 ref. [in Polish].

41. Piątek J, Maćkowiak P, Krauss H, Nowak D, Bogdański P. In vivo investigations of neurotensin receptors in adipocytes, hepatocytes and enterocytes of rat. Ann Agric Environ Med 2011;18(2):433-6, 28 ref.

42. Rudziński R, Banach J. The effect of tobacco smoke on the course and severity of inflammation in periodontal tissues. Ann Acad Med Stetin 2011;57(1):88-95, 39 ref. [in Polish].

43. Sapota A, Darago A, Wagrowska-Koski E. Cobalt. Documentation. Podst Met Oceny Srod Pr 2011;27(3): 47-94, 256 ref. [in Polish].

44. Sapota A, Skrzypińska-Gawrysiak M, WągrowskaKoski E. 2-Etoxyethanol. Documentation. Podst Met Oceny Srod Pr 2011;27(2):57-92, 112 ref. [in Polish].

45. Sapota A, Skrzypińska-Gawrysiak M, WagrowskaKoski E. 2-Ethoxyethyl acetate. Documentation. Podst Met Oceny Srod Pr 2011;27(2):145-67, 76 ref. [in Polish].

46. Sapota A, Skrzypińska-Gawrysiak M, WagrowskaKoski E. Nitroethane. Documentation. Podst Met Oceny Srod Pr 2011;27(3):155-70, 33 ref. [in Polish].

47. Siemińska A. When does nicotine dependence begin? Pneumonol Alergol Pol 2011;79(5):357-64, 64 ref. [in Polish]. 
48. Sikorska-Jaroszyńska MHJ， Mielnik-Błaszczak M, Krawczyk D, Nasiłowska-Barud A. Smoking and the level of nicotine addiction in relation to the state of hard dental tissues in young adults. Ann Agric Environ Med 2011;18(2):415-9, 22 ref.

49. Sitarek K, Wagrowska-Koski E. Hydrogenated terphenyls. Documentation. Podst Met Oceny Srod Pr 2011;27(3):171-88, 11 ref. [in Polish].

50. Sławińska-Ochla T, Ignasiak Z, Fugiel J, Pokrywka J. Lead concentration in blood school children from Copper Mining area and the level of somatic development at birth. Med Srod 2011;14(4):42-8, 29 ref. [in Polish].

51. Soćko R, Czerczak S, Wągrowska-Koski E. Methyl isocyanate. Documentation. Podst Met Oceny Srod Pr 2011;27(2):93-116, 67 ref. [in Polish].

52. Soćko R, Czerczak S, Wągrowska-Koski E. Ethyl cyanoacrylate. Documentation. Podst Met Oceny Srod Pr 2011;27(3):31-45, 37 ref. [in Polish].

53. Soćko R, Czerczak S, Wągrowska-Koski E. Tetramethyl succinonitrile. Documentation. Podst Met Oceny Srod Pr 2011;27(4):151-65, 19 ref. [in Polish].

54. Sroka J, Karamon J, Cencek T, Dutkiewicz J. Preliminary assessment of usefulness of cELISA test for screening pig and cattle populations for presence of antibodies against Toxoplasma gondii. Ann Agric Environ Med 2011;18(2):335-9, 31 ref.

55. Starek A, Jakubowski M, Wagrowska-Koski E. Copper and its inorganic compounds. Documentation. Podst Met Oceny Srod Pr 2011;27(2):117-44, 83 ref. [in Polish].

56. Starek A, Wagrowska-Koski E. Tributyltin compounds (IV). Documentation. Podst Met Oceny Srod Pr 2011;27(3):189-218, 86 ref. [in Polish].

57. Stetkiewicz J, Wągrowska-Koski E. Hydrogen sulfide. Documentation. Podst Met Oceny Srod Pr 2011;27(4):97-117, 84 ref. [in Polish].

58. Strumylaite L, Mechonosina K. Cadmium carcinogenesis - some key points. Med Srod 2011;14(3):13-5, 16 ref.
59. Szymańska JA, Frydrych B, Wagrowska-Koski E. 3,7-Dimethyl-2,6-octadienal (citral). Documentation. Podst Met Oceny Srod Pr 2011;27(4):21-41, 36 ref. [in Polish].

60. Świercz R, Wąsowicz W, Stetkiewicz J, Gromadzińska J, Majcherek W. 4-Week inhalation toxicity of 2-methylnaphthalene in experimental animals. Int J Occup Med Environ Health 2011;24(4):399-408, 14 ref. DOI: 10.2478/s13382-011-0036-9.

61. Wąsowicz W, Cieślak M, Palus J, Stańczyk M, Dziubałtowska E, Stępnik M, et al. Evaluation of biological effects of nanomaterials. Part I. Cyto-and genotoxicity of nanosilver composites applied in textile technologies. Int J Occup Med Environ Health 2011;24(4):34858, 42 ref. DOI: 10.2478/s13382-011-0041-z.

62. Wierzbowska J. Preservatives in topical ophthalmic medications - similarities and differences. Okulistyka 2011;(2, Suppl I):134-6, 24 ref. [in Polish].

63. Wysokiński D, Skłodowska A, Dorecka M, Romaniuk D, Błasiak J, Szaflik JP. The association of the $44062 G>A$ polymorphism in the transferrin gene and tobacco smoking in age-related macular degeneration (AMD). Okulistyka 2011;(2, Suppl I):32-7, 20 ref. [in Polish].

64. Zwierzchowski G, Miciński J, Górecka-Ordon E, Goławski P. Is food allergy a civilization-related disease? Pol Ann Med 2011;18(1):168-76, 22 ref.

65. Żurawski P, Stryła W. Biological effects of low frequency electromagnetic fields on a human body. Probl Hig Epidemiol 2011;92(2):167-72, 50 ref. [in Polish].

\section{OCCUPATIONAL PATHOLOGY}

1. Bzdega J, Janiak MK, Lach J, Lasocki K, Kubiak L. Carcinogenic factors at work stations in the units of the Polish Armed Forces in the years 2005-2009. Lek Wojsk 2011;89(3):206-8, 12 ref. [in Polish]. 
2. Cassini C, Calloni C, Bartolini G, Garcia SC, Dornelles MA, Pegas Henriques JA, et al. Occupational risk assessment of oxidative stress and genotoxicity in workers exposed to paints during a working week. Int J Occup Med Environ Health 2011;24(3):308-19, 51 ref. DOI: 10.2478/s13382-011-0030-2.

3. Cisak E, Zwoliński J, Chmielewska-Badora J, Dutkiewicz J, Wójcik-Fatla A, Zając V. Analysis of the state of knowledge and awareness in the area of tick-borne diseases prophylaxis in the population at occupational risk. Zdrow Publiczne 2011;121(1):47-51, 27 ref.

4. Czajkowski G, Kałużny BJ, Malukiewicz G.Application of the spectral coherence tomography in dry eye syndrome diagnosis. Okulistyka 2011;(3):36-9, 15 ref. [in Polish].

5. Czarnecka-Operacz M. Contemporary guidelines on diagnosis of urticaria. Przegl Dermatol 2011;98(1):1922, 4 ref. [in Polish].

6. Domański W, Makles Z. Hazards caused by chemical agents at selected workstations in the shoe industry. Bezpiecz Pr 2011;(1):18-21, 12 ref. [in Polish].

7. Dorko E, Rimarova K, Kecerova A, Pilipcinec E, Dudrikova E, Lovayova V, et al. Potential association between Coxiella burnetii seroprevalence and selected risk factors among veterinary students in Slovakia. Ann Agric Environ Med 2011;18(1):47-53, 34 ref.

8. Dutkiewicz J, Cisak E, Sroka J, Wójcik-Fatla A, Zając V. Biological agents as occupational hazards - selected issues. Ann Agric Environ Med 2011;18(2):286-93, 152 ref.

9. Elenge MM, de Brouwer C. Identification of hazards in the workplaces of artisanal mining in Katanga. Int $\mathrm{J}$ Occup Med Environ Health 2011;24(1):57-66, 24 ref. DOI: 10.2478/s13382-011-0012-4.

10. Gać P, Waliszewska-Prosół M, Poręba R, Zawadzki M, Pawlas K. Neurological occupational diseases in Poland. Bezpiecz Pr 2011;(7-8):20-3, 12 ref. [in Polish].

11. Garus-Pakowska A. Workload impact on compliance with hygiene procedures in medical personnel. Med Pr 2011;62(4):369-76, 14 ref. [in Polish].
12. Garus-Pakowska A, Szatko F. Percutaneous exposures in medical personnel. Med Pr 2011;62(5):473-80, 30 ref. [in Polish].

13. Golińska-Zach A, Krawczyk-Szulc P, Walusiak-Skorupa J. Etiology, determinants, diagnostics and prophylaxis of occupational allergic respiratory diseases in hairdressers. Med Pr 2011;62(5):517-26, 54 ref. [in Polish].

14. Gołofit-Szymczak M, Ławniczek-Wałczyk A. Biomass as a source of biological hazards. Bezpiecz Pr 2011;(12):17-9, 12 ref. [in Polish].

15. Hallas TE, Gislason T, Gislason D. Mite allergy and mite exposure in Iceland. Ann Agric Environ Med 2011;18(1):13-7, 24 ref.

16. Hejmdalski W. Risk factors in antiquity conservation. Bezpiecz Pr 2011;(5):20-3, 10 ref. [in Polish].

17. Hwang-Bo G, Lee JH. Effects of kinesio taping in a physical therapist with acute low back pain due to patient handling: A case report. Int J Occup Med Environ Health 2011;24(3):320-3, 15 ref. DOI: 10.2478/s13382011-0029-8.

18. Jankowska E. Nano-objects at workplaces. Podst Met Oceny Srod Pr 2011;27(4):7-20, 32 ref. [in Polish].

19. Jędrejko M, Skoczyńska A. Color vision impairment in workers exposed to mercury vapor. Med Pr 2011;62(3):227-35, 19 ref. [in Polish].

20. Jurewicz J, Hanke W, Sobala W, Ligocka D, GaworaZiółek M. Occupational exposure to pesticides among farmers of the Łódź voivodeship agricultural area. Med Pr 2011;62(1):9-16, 14 ref. [in Polish].

21. Kapka-Skrzypczak L, Cyranka M, Skrzypczak M, Kruszewski M. Biomonitoring and biomarkers of organophosphate pesticides exposure - state of the art. Ann Agric Environ Med 2011;18(2):294-303, 78 ref.

22. Karczewicz D, Drobek-Słowik M. Computer vision syndrome - Do we have a new 21st century epidemic? Okulistyka 2011;(4):76-7, 20 ref. [in Polish].

23. Karpowicz J, Gryz K, Politański P, Zmyślony M. Exposure to static magnetic field and health hazards during 
the operation of magnetic resonance scanners. Med Pr 2011;62(3):309-21, 53 ref. [in Polish].

24. Kierklo A, Kobus A, Jaworska M, Botuliński B. Work-related musculoskeletal disorders among dentists - A questionnaire survey. Ann Agric Environ Med 2011;18(1):79-84, 21 ref.

25. Konieczko K, Polańska K, Hanke W. Protection against environmental tobacco smoke exposure according to EU and Polish legislation. Med Pr 2011;62(4): 415-24, 30 ref. [in Polish].

26. Korzeniewski K, Pluta J, Prokop E, Brzozowski R. The analysis of diseases and injuries occurring in the population of soldiers from the Polish Military Contingent deployed to Afghanistan in 2009. Lek Wojsk 2011;89(3):185-93, 46 ref. [in Polish].

27. Korzeniewski K, Krall J. Prevalence of dental diseases among soldiers serving in the Polish Military Contingent in Afghanistan. Lek Wojsk 2011;89(4):310-6, 14 ref. [in Polish].

28. Kose S, Mandiracioglu A, Murat Oral A, Emek M, Gozaydin A, Kuzucu L, et al. Seroprevalence of hepatitis $B$ and $C$ viruses: awareness and safe practices of hairdressers in Izmir - A survey. Int J Occup Med Environ Health 2011;24(3):275-82, 24 ref. DOI: 10.2478/ s13382-011-0032-0.

29. Kozajda A, Szadkowska-Stańczyk I. Exposure to biological agents used in Polish enterprises: Analysis of data derived from the National Register of Biological Agents. Med Pr 2011;62(2):145-52, 8 ref. [in Polish].

30. Kozajda A, Szadkowska-Stańczyk I. Protection of medical diagnostic laboratory workers against biohazards. Med Pr 2011;62(3):291-5, 28 ref. [in Polish].

31. Krause M. Actual requirements and guidelines concerning occupational exposure assessment for optical radiation. Pr Zdrow Bezpiecz 2011;(1):1-7, 11 ref. [in Polish].

32. Krauss A, Krauss H, Waliszewska B, Piątek J. Selected environmental aspects of the introduction into the Polish market of exotic wood species on the example of caviuna (Machaerium scleroxylon Tul.). Ann Agric Environ Med 2011;18(2):345-9, 21 ref.

33. Krzemińska S, Irzmańska E. Exposure to mineral oils at worksites and novel solutions for polymer protective materials in selected personal protective equipment. Med Pr 2011;62(4):435-43, 39 ref. [in Polish].

34. Krzyczmanik D, Rybacki M, Wittczak T, Dudek W, Świerczyńska-Machura D, Pałczyński C, et al. Coexistence of two occupational infectious diseases in one patients - borreliosis and tick-borne encephalitis - A case report. Med Pr 2011;62(3):339-44, 14 ref. [in Polish].

35. Kurnatowski P, Warpechowska M, Kurnatowska AJ. Knowledge on Lyme disease among foresters. Int J Occup Med Environ Health 2011;24(1):78-93, 24 ref. DOI: 10.2478/s13382-011-0001-0.

36. Kurpiewska J, Liwkowicz J. Occupational dermatitis occurrences in European Union. Bezpiecz Pr 2011;(6): 24-6, 14 ref. [in Polish].

37. Lange J, Mastrangelo G, Cegolon L. Asbestos abatement workers versus asbestos workers: exposure and health-effects differ [letter to the editor]. Int J Occup Med Environ Health 2011;24(4):418-9, 6 ref. DOI: 10.2478/s13382-011-0039-6.

38. Laudańska-Olszewska I, Biesiadzka M, Omulecka M. Ophthalmological assessment of driving ability of drivers at the age more than 60 years. Klin Oczna 2011;113 (4-6):156-60, 13 ref. [in Polish].

39. Lembas-Bogaczyk J, Długosz A, Tokarczyk I. Assessment of exposure to carbon monoxide group of firefighters from fire fighting and rescue units. Med Srod 2011;14(1):18-23, 11 ref. [in Polish].

40. Lipińska-Ojrzanowska A, Wittczak T, Krzyczmanik D, Pałczyński C, Walusiak-Skorupa J. Invasion by trichinae in the patient hospitalized with suspicion of occupational borreliosis: A case report. Med Pr 2011;62(1): 73-6, 6 ref. [in Polish]. 
41. Lipińska-Ojrzanowska A, Wittczak T, Pałczyński C, Walusiak-Skorupa J. Cleaners' asthma - etiology, diagnostics, prophylaxis and medical certification. Med Pr 2011;62(2):163-73, 47 ref. [in Polish].

42. Lipińska-Ojrzanowska A, Rybacki M, Wiszniewska M, Pałczyński C, Walusiak-Skorupa J. Prophylactic care of apprentices occupationally exposed to allergens. Med Pr 2011;62(4):403-13, 48 ref. [in Polish].

43. Maciejewska B, Milanowski J. The importance of spirometry in the diagnosis and treatment of asthma. Zdrow Publiczne 2011;121(2):186-90, 19 ref. [in Polish].

44. Marcinkiewicz A, Szosland D. New medical standards for evaluation of driving predispositions of people suffering from diabetes mellitus. Med Pr 2011;62(5):53742, 27 ref. [in Polish].

45. Niebudek-Bogusz E, Grygiel J, Strumiłło P, Śliwińska-Kowalska M. Mel cepstral analysis of voice in patients with vocal nodules. Otorynolaryngologia 2011;10(4):176-81, 23 ref. [in Polish].

46. Niedziałek S, Duda-Zalewska A. Health needs of professional drivers. Probl Hig Epidemiol 2011;92(2):21620, 6 ref. [in Polish].

47. Olszewska J. Rehabilitation for chronic obstructive pulmonary disease patients. Pol Ann Med 2011;18(1): 177-87, 23 ref.

48. Pabin T, Karczewicz D. Influence of work at the computer LCD monitors on selected functions of the organ of vision. Okulistyka 2011;(4):39-42, 8 ref. [in Polish].

49. Sikora P. The occupational risk assessment for an artist on example of the workplace of a teacher of wood sculpture. Pr Zdrow Bezpiecz 2011;(1):11-7, 8 ref. [in Polish].

50. Sińczuk-Walczak H. Comments on diagnostic problems and procedures in certifying the ability of epileptic patients to drive motor vehicles based on published articles and our own cases. Med Pr 2011;62(4):395-402, 32 ref. [in Polish].
51. Smagowska B. Noise at workplaces in call center. Bezpiecz Pr 2011;(4):22-5, 16 ref. [in Polish].

52. Solecki L. Low back pain among farmers exposed to whole body vibration: A literature review. Med Pr 2011;62(2):187-202, 41 ref. [in Polish].

53. Stojek NM. The risk on contact people with different serotypes of sticks the Yersinia. Med Srod 2011;14(1): 29-33, 21 ref. [in Polish].

54. Szczegielniak J, Bogacz K, Łuniewski J, Majorczyk E, Tukiendorf A, Czerwiński M. The influence of physiotherapy on the concentration of interleukin-8 in patients suffering from chronic obstructive pulmonary disease. Pneumonol Alergol Pol 2011;79(3):184-8, 25 ref. [in Polish].

55. Szczyrek M, Krawczyk P, Milanowski J, Jastrzębska I, Zwolak A, Daniluk J. Chronic obstructive pulmonary disease in farmers and agricultural workers - An overview. Ann Agric Environ Med 2011;18(2):310-3, 37 ref.

56. Szeszenia-Dąbrowska N, Świątkowska B, Szubert Z, Wilczyńska U. Asbestos in Poland: Occupational health problems. Int J Occup Med Environ Health 2011;24(2):142-52, 25 ref. DOI: 10.2478/ s13382-011-0020-4.

57. Szewczyńska M, Dobrzyńska E, Pośniak M, Jeżewska A. Chemical agents in hair salons - hazards and prevention. Bezpiecz Pr 2011;(1):14-7, 10 ref. [in Polish].

58. Szmyd K, Haus O. Cancers among medical personnel exposed to anticancer agents. Med Pr 2011;62(1): 17-21, 15 ref. [in Polish].

59. Szubert Z, Stankiewicz-Choroszucha B, WrońskaSobolewska M, Cwynar E, Dobrowolska J, Wróbel $\mathrm{R}$, et al. Implementation of the Amiantus project involving prophylactic medical examinations of the former employees of asbestos processing plants. Med Pr 2011;62(5):465-72, 11 ref. [in Polish].

60. Świderska-Kiełbik S, Krakowiak A, Wiszniewska M, Nowakowska-Świrta E, Walusiak-Skorupa J, Śliwkiewicz $\mathrm{K}$, et al. Occupational allergy to birds within the 
population of Polish bird keepers employed in zoo gardens. Int J Occup Med Environ Health 2011;24(3): 292-303, 23 ref. DOI: 10.2478/s13382-011-0027-x.

61. Świerczyńska-Machura D, Walusiak-Skorupa J, Wiszniewska M, Lipińska-Ojrzanowska A, Wittczak T, Dudek W, et al. The real value of diagnostic methods in case of long time of cessation of occupational exposure to diisocyanates among patients diagnosed in the Nofer Institute of Occupational Medicine in Łódź. Med Pr 2011;62(6):567-77, 33 ref. [in Polish].

62. Talebi-Taher M, Javad-Moosavi SA, Entezari AH, Shekarabi M, Parhizkar B. Comparing the performance of QuantiFERON-TB Gold and Mantoux test in detecting latent tuberculosis infection among Iranian health care workers. Int J Occup Med Environ Health 2011;24(4):359-66, 35 ref. DOI: 10.2478/ s13382-011-0046-7.

63. Tonini S, Candura SM, Lanfranco A, Mennoia NV. Carpometacarpal subchondral cysts due to repetitive movements in shoemaker: A case report. Int J Occup Med Environ Health 2011;24(4):414-7, 12 ref. DOI: 10.2478/s13382-011-0042-y.

64. Tsapko VG, Chudnovets AJ, Sterenbogen MJ, Papach VV, Dutkiewicz J, Skórska C, et al. Exposure to bioaerosols in the selected agricultural facilities of the Ukraine and Poland - A review. Ann Agric Environ Med 2011;18(1):19-27, 72 ref.

65. Tymoszuk D, Wittczak T, Walusiak-Skorupa J, Pałczyński C. Occupational allergy in transport workers - underestimated hazard. Med Pr 2011;62(6): 633-41, 57 ref. [in Polish].

66. Uziębło-Życzkowska B, Dziuk M, Gielerak G. Causes and prevention of sudden cardiac death in young soldiers. Lek Wojsk 2011;89(3):225-31, 25 ref. [in Polish]. 67. Walusiak-Skorupa J, Wiszniewska M, KrawczykSzulc P, Rybacki M, Wągrowska-Koski E. Prophylactic care of workers with disabilities - the problem of contemporary occupational health service? Med Pr 2011;62(2): 175-86, 39 ref. [in Polish].

68. Warchoł-Sławińska E, Książek P, Furtak M, Włoch K, Drop B, Drop K. Inability to work in chosen mental illnesses. Zdrow Publiczne 2011;121(1):81-5, 6 ref.

69. Wągrowska-Koski E, Lewańska M, Rybacki M, Turbańska R, Mikołajczyk A, Łoś-Spychalska T. Evaluation of vibration exposure long-term effects in people with diagnosed vibration syndrome. Med Pr 2011;62(2):10312, 27 ref. [in Polish].

70. Wiszniewska M, Pałczyński C, Krawczyk-Szulc P, Wittczak T, Cyran A, Walusiak-Skorupa J. Occupational allergy to Limonium sinuatum - A case report. Int J Occup Med Environ Health 2011;24(3):304-7, 11 ref. DOI: 10.2478/s13382-011-0025-z.

71. Wolska A, Latała A. Assessment of the occupational risk related to exposition to natural ultraviolet radiation. Bezpiecz Pr 2011;(7-8):12-6, 13 ref. [in Polish].

72. Wolska A, Pośniak M, Szewczyńska M. Solar UV and phototoxic chemical substances - occupational risk assessment. Bezpiecz Pr 2011;(10):13-7, 9 ref. [in Polish].

73. Woźnicka E, Niebudek-Bogusz E, Śliwińska-Kowalska M. Effects of voice therapy in a patient with paralytic dysphonia - A case study. Otorynolaryngologia 2011;10(3):138-45, 30 ref. [in Polish].

74. Zabłocka-Słowińska K, Limburska J, Prescha A, Pieczyńska J, Tomczyk J, Grajeta H. Assessment of energy and macronutrients supply in daily food rations of people exposed to hand transmitted vibrations. Med Pr 2011;62(6):583-90, 23 ref. [in Polish].

75. Zamysłowska-Szmytke E, Śliwińska-Kowalska M.Normative values of kinetic tests in VNG assessment. Med Pr 2011;62(3):237-46, 14 ref. [in Polish].

76. Złotkowska R, Brewczyński PZ, Dąbkowska B, Muszyńska-Graca M, Skiba M, Wylężek P. Prevalence and risk factors for the cardiovascular diseases in the population of municipal bus drivers. Med Srod 2011;14(3):49-53, 13 ref. [in Polish]. 


\section{EPIDEMIOLOGICAL STUDIES}

1. Aaro LE, Herbeć A, Bjorngaard JH, Mańczuk M, Zatoński WA. Depressive episodes and depressive tendencies among a sample of adults in Kielce, south-eastern Poland. Ann Agric Environ Med 2011;18(2):273-8, 19 ref.

2. Bahr DE, Aldrich TE, Seidu D, Brion GM, Tollerud DJ, Muldoon S, et al. Occupational exposure to trichloroethylene and cancer risk for workers at the Paducah Gaseous Diffusion Plant. Int J Occup Med Environ Health 2011;24(1):67-77, 25 ref. DOI: 10.2478/ s13382-011-0007-1.

3. Bartosik K, Lachowska-Kotowska P, Szymańska J, Wójcik-Fatla A, Pabis A, Buczek A. Environmental conditioning of incidence of tick-borne encephalitis in the south-eastern Poland in 1996-2006. Ann Agric Environ Med 2011;18(1):119-26, 71 ref.

4. Bartosik K, Lachowska-Kotowska P, Szymańska J, Pabis A, Buczek A. Lyme borreliosis in south-eastern Poland: relationships with environmental factors and medical attention standards. Ann Agric Environ Med 2011;18(1):131-7, 60 ref.

5. Baumann-Popczyk A. Hepatitis E as zoonosis. Przegl Epidemiol 2011;65(1):9-13, 25 ref. [in Polish].

6. Baumann-Popczyk A. Hepatitis A in Poland in 2009. Przegl Epidemiol 2011;65(2):255-8 [in Polish].

7. Boffetta P. Internal and external validity of cohort studies. Ann Agric Environ Med 2011;18(2):283-4, 3 ref.

8. Bojar I, Bilińnki P, Boyle P, Zatoński W, Marcinkowski JT, Wojtyła A. Prevention of female reproductive system cancer among rural and urban Polish pregnant women. Ann Agric Environ Med 2011;18(1):183-8, 17 ref.

9. Boyle P. Improving health in central and eastern Europe. Ann Agric Environ Med 2011;18(2):281-2, 4 ref.

10. Broding HC, Frank P, Hoffmeyer F, Bunger J. Course of occupational asthma depending on the duration of workplace exposure to allergens - a retrospective cohort study in bakers and farmers. Ann Agric Environ Med 2011;18(1):35-40, 19 ref.
11. Brudnowska J, Pepłońska B. Night shift work and cancer risk: A literature review. Med Pr 2011;62(3): 323-38, 33 ref. [in Polish].

12. Bugajska J, Jędryka-Góral A, Gasik R, ŻołnierczykZreda D. Acquired musculoskeletal dysfunction syndromes in workers in the light of epidemiological studies. Med Pr 2011;62(2):153-61, 44 ref. [in Polish].

13. Bugajska J, Żołnierczyk-Zreda D, Jędryka-Góral A. The role of psychosocial work factors in the development of musculoskeletal disorders in workers. Med $\operatorname{Pr}$ 2011;62(6):653-8, 35 ref. [in Polish].

14. Bzdega J, Lach J, Janiak MK, Lasocki K, Kubiak L. Incidence of the selected infectious diseases among the Polish Armed Forces compulsory servicemen from 2005 to 2007. Lek Wojsk 2011;89(4):317-21, 8 ref. [in Polish].

15. Cianciara D, Goryński P, Seroka W. Migrants' hospitalization in Poland. Probl Hig Epidemiol 2011;92(3): 497-503, 19 ref. [in Polish].

16. Czarkowski MP, Romanowska M, Staszewska E, Stefańska I, Donevski S, Brydak LB. Influenza in Poland in 2009. Przegl Epidemiol 2011;65(2):199-203 [in Polish].

17. El-Helaly M, Abdel-Elah K, Haussein A, Shalaby H. Paternal occupational exposures and the risk of congenital malformations - A case-control study. Int J Occup Med Environ Health 2011;24(2):218-27, 43 ref. DOI: 10.2478/s13382-011-0019-x.

18. Furman S, Napiórkowska A, Sadkowska-Todys M. Yersiniosis in Poland in 2009. Przegl Epidemiol 2011;65(2):235-8 [in Polish].

19. Gajewska M, Goryński P, Wysocki MJ. Obesity and type 2 diabetes as main causes of hospitalization in Polish hospitals in 2008. Probl Hig Epidemiol 2011;92(1): 132-6, 28 ref. [in Polish].

20. Gawor J. Potential risk factors for alveolar echinococcosis in humans in Poland. Przegl Epidemiol 2011;65(3):465-70, 24 ref. [in Polish]. 
21. Gorczyca T, Góra J, Gorczyca D, Maciejewska B, Palczak R. Traffic accidents involving pedestrians - A problem of modern medicine and public health. Zdrow Publiczne 2011;121(1):90-4, 20 ref. [in Polish].

22. Gustafsson K, Marklund S. Consequences of sickness presence and sickness absence on health and work ability: A Swedish prospective cohort study. Int J Occup Med Environ Health 2011;24(2):153-65, 43 ref. DOI: 10.2478/s13382-011-0013-3.

23. Hudzik G, Wodzisławska-Czapla D. Threats related to the presence of eggs of intestinal parasites in sludge. Przegl Epidemiol 2011;65(3):459-63, 13 ref. [in Polish].

24. Ilow R, Regulska-Ilow B, Różańska D, Zatońska K, Dehghan M, Zhang X, et al. Assessment of dietary intake in a sample of Polish population - baseline assessment from the prospective cohort 'PONS' study. Ann Agric Environ Med 2011;18(2):229-34, 33 ref.

25. Ilow R, Regulska-Ilow B, Różańska D, Zatońska K, Dehghan M, Zhang X, et al. Evaluation of mineral and vitamin intake in the diet of a sample of Polish population - baseline assessment from the prospective cohort 'PONS' study. Ann Agric Environ Med 2011;18(2): 235-40, 28 ref.

26. Islami F, Mańczuk M, Vedanthan R, Vatten L, Polewczyk A, Fuster V, et al. A cross-sectional study of cardiovascular disease and associated factors. Ann Agric Environ Med 2011;18(2):255-9, 19 ref.

27. Jabłonowska E, Małolepsza E, Strycharz M, Wójcik K. Malignancy cases in HIV-positive patients in Lodz region in years 1992-2010. Przegl Epidemiol 2011;65(2): 33943, 14 ref. [in Polish].

28. Janszky I, Vatten L, Romundstad P, Laugsand LE, Bjorngaard JH, Mańczuk M, et al. Metabolic syndrome in Poland - the PONS study. Ann Agric Environ Med 2011;18(2):270-2, 18 ref.

29. Jodkowska M, Oblacińska A, Tabak I, Mikiel-Kostyra K. Overweight and obesity among parents and their 13-old children in Poland. Przegl Epidemiol 2011;65(3):497-502, 25 ref. [in Polish].

30. Jurewicz J, Hanke W. Exposure to phthalates: reproductive outcomes and children health. A review of epidemiological studies. Int J Occup Med Environ Health 2011;24(2):115-41, 90 ref. DOI: 10.2478/ s13382-011-0022-2.

31. Kłosiewicz-Latoszek L, Cybulska B. Sugar and health hazard of obesity, diabetes mellitus and cardiovascular diseases. Probl Hig Epidemiol 2011;92(2):1816, 38 ref. [in Polish].

32. Kołosza Z, Zemła B, Banasik T. Survival of cervical cancer patients in Silesia in the years 1999-2001. Med Srod 2011;14(2):32-8, 15 ref. [in Polish].

33. Korzeniewska-Koseła M. Tuberculosis in Poland in 2009. Przegl Epidemiol 2011;65(2):301-5 [in Polish]. 34. Kossakowska-Krajewska A. Selected bacterial zoonoses in medical practice. Pol Ann Med 2011;18(1): 146-55, 20 ref.

35. Kowalska M, Humeniuk M, Danso F, Kułak E, Arasiewicz H. Quality of life of occupationally active people, aged 45-60, living in the Polish industrial region (Silesian agglomeration). Med Pr 2011;62(5):455-63, 17 ref. [in Polish].

36. Kowalska M, Zejda JE, Bugajska J, Braczkowska B, Brożek G, Malińska M. Eye symptoms in office employees working at computer stations. Med Pr 2011;62(1): 1-8, 21 ref. [in Polish].

37. Krzyżak M, Maślach D, Bielska-Lasota M, Maksimowicz K, Karpińska M, Łapińska U, et al. Breast cancer threat in the Podlaskie voivodeship before the introduction of the Population Screening Program. Probl Hig Epidemiol 2011;92(1):35-9, 24 ref. [in Polish].

38. Król SK, Kapka-Skrzypczak L. Human colon cancers as a major problem in Poland and in the world - medical and environmental issues. Med Srod 2011;14(4): 75-80, 17 ref. [in Polish]. 
39. Książek P, Herda J, Raszewska M, Kawałek M, Mojsym S. Bacterial sexually transmitted-diseases - the threat of the 21st century. Zdrow Publiczne 2011;121(2): 162-6, 21 ref.

40. Laprus I, Adamek M, Kozielski J. The need of lung cancer screening - new evidence, new expectations. Pneumonol Alergol Pol 2011;79(6):419-27, 58 ref. [in Polish].

41. Łepecka-Klusek C, Wdowiak A, Pilewska-Kozak AB, Syty K, Jakiel G. The role of age, environmental and occupational factors on semen density. Ann Agric Environ Med 2011;18(2):437-40, 29 ref.

42. Łobaszewski J, Przewoźniak K, Zatońska K, Wojtyła A, Bylina J, Mańczuk M, et al. Patterns of leisure time physical activity and its determinants among a sample of adults from Kielce region, Poland - the 'PONS' study. Ann Agric Environ Med 2011;18(2): 241-5, 19 ref.

43. Milewska J, Pluta J, Czarniecki M, Korzeniewski K. Cholera - a particulary dangerous disease in the area of deployment of Polish Military Contingent soldiers in Afghanistan. Lek Wojsk 2011;89(3):236-42, 29 ref. [in Polish].

44. Mishra PK, Bhargava A, Pathak N, Desikan P, Maudar KK, Varshney S, et al. Molecular surveillance of hepatitis and tuberculosis infections in a cohort exposed to methyl isocyanate. Int J Occup Med Environ Health 2011;24(1):94-101, 27 ref. DOI: 10.2478/ s13382-011-0006-2.

45. Mrożek-Budzyn D, Majewska R, Kiełtyka A, Augustyniak M. Lack of association between Thimerosal-containing vaccines and autism. Przegl Epidemiol 2011;65(3):491-5, 17 ref. [in Polish].

46. Olszyńska-Krowicka M. Dengue as haemorrhagic fever. Przegl Epidemiol 2011;65(4):567-9, 18 ref. [in Polish].

47. Olszyńska-Krowicka M, Świtaj K. Dengue in patients hospitalized in the Hospital Ward of Zoonoses and Tropical Diseases in Warsaw in years 2002-2011. Przegl Epidemiol 2011;65(4):571-5, 9 ref. [in Polish].
48. Paciorek M, Przyjałkowski W, Lipowski D, Czekalska-Lachowicz E, Horban A. Listeriosis of the central nervous system: epidemiological and diagnostic aspects - own observations. Przegl Epidemiol 2011;65(1): 63-6, 18 ref. [in Polish].

49. Pancer K, Napiórkowska A, Gut W, StypułkowskaMisiurewicz H. Demographic characteristics of reported cases of legionellosis in years 2005-2009 in Poland in comparison to EWGLI data. Przegl Epidemiol 2011;65(3):433-9, 14 ref. [in Polish].

50. Paradowska-Stankiewicz I, Chrześcijańska I. Lyme borreliosis in Poland in 2009. Przegl Epidemiol 2011;65(2):279-80 [in Polish].

51. Pędziński B, Kurianiuk A, Pędziński W, Szpak A. Cardiovascular disease risk assessment based on prophylactic program realised in primary health care. Probl Hig Epidemiol 2011;92(3):397-402, 21 ref. [in Polish].

52. Polańska K, Hanke W, Sobala W, Brzeźnicki S, Ligocka D. Predictors of environmental exposure to polycyclic aromatic hydrocarbons among pregnant women - prospective cohort study in Poland. Int J Occup Med Environ Health 2011;24(1):8-17, 16 ref. DOI: 10.2478/ s13382-011-0003-5.

53. Polańska K, Hanke W, Konieczko K. Hospitality workers' exposure to environmental tobacco smoke before and after implementation of smoking ban in public places: A review of epidemiological studies. Med Pr 2011;62(2):211-24, 54 ref. [in Polish].

54. Polańska K, Hanke W, Konieczko K. Impact of the legislation for smoke-free workplaces on respiratory health in hospitality workers - review of epidemiological studies. Med Pr 2011;62(3):297-308, 44 ref. [in Polish].

55. Polańska K, Hanke W, Jurewicz J, Sobala W, Madsen C, Nafstad P, et al. Polish Mother and Child Cohort Study (REPRO_PL) - methodology of follow-up of the children. Int J Occup Med Environ Health 2011;24(4):391-8, 18 ref. DOI: 10.2478/ s13382-011-0026-y. 
56. Poznańska A, Wojtyniak B, Seroka W. Main causes of death among Polish population in 2030. Przegl Epidemiol 2011;65(3):483-9, 6 ref. [in Polish].

57. Przewoźniak K, Łobaszewski J, Cedzyńska M, Wojtyła A, Paprzycki P, Mańczuk M, et al. Cigarette smoking among a sample of PONS study subjects: preliminary assessment. Ann Agric Environ Med 2011;18(2):215-20, 18 ref.

58. Przewoźniak K, Łobaszewski J, Wojtyła A, Bylina J, Mańczuk M, Zatoński WA. Alcohol drinking patterns and habits among a sample of PONS study subjects: preliminary assessment. Ann Agric Environ Med 2011;18(2):221-8, 21 ref.

59. Przybyłowicz K, Kalinowska K. Pregnant women nutrition and newborn status expressed as Ponderal Index. Probl Hig Epidemiol 2011;92(3):508-11, 20 ref. [in Polish].

60. Rogowska-Szadkowska D, Chlabicz S. Where and how do Polish patients contract HIV? Przegl Epidemiol 2011;65(3):509-13, 17 ref.

61. Romundstad P, Janszky I, Vatten L, Bjorngaard JH, Langhammer A, Mańczuk M, et al. Cancer risk factors in Poland: the PONS study. Ann Agric Environ Med 2011;18(2):251-4, 6 ref.

62. Rosińska M, Stępień M. Hepatitis C in Poland in 2009. Przegl Epidemiol 2011;65(2):265-9 [in Polish].

63. Rubinsztajn R, Chazan R. Mortality and comorbidity in hospitalized chronic obstructive pulmonary disease patients. Pneumonol Alergol Pol 2011;79(5):3436, 13 ref. [in Polish].

64. Salameh P, Khayat G, Waked M. Validation of the respiratory toxics exposure score (RTES) for chronic obstructive pulmonary disease screening. Int J Occup Med Environ Health 2011;24(4):339-47, 33 ref. DOI: 10.2478/ s13382-011-0043-x.

65. Słowińska M, Koter-Michalak M, Bukowska B. The effect of dioxins on the human organism - epidemiological studies. Med Pr 2011;62(6):643-52, 37 ref. [in Polish].
66. Stanislavoviene J, Pajarskiene B, Jankauskas R, Veniute M. The psychosocial factors at work related to depression among female white-collar workers in Vilnius (Lithuania). Int J Occup Med Environ Health 2011;24(2):166-76, 36 ref. DOI: 10.2478/ s13382-011-0018-y.

67. Stankiewicz-Choroszucha BL, Wawrzyniak ZM, Lipiec A, Piekarska B, Kapalczynski WJ, SamolińskiBK. Consequences of smoke inhalation in the 'Epidemiology of Allergic Diseases in Poland' project (ECAP). Ann Agric Environ Med 2011;18(2):420-8, 36 ref.

68. Staśkiewicz G, Czekajska-Chehab E, Przegaliński J, Maciejewski M, Pachowicz M, Drop A. Meteorological parameters and severity of acute pulmonary embolism episodes. Ann Agric Environ Med 2011;18(1): 127-30, 25 ref.

69. Stępień M. Malaria in Poland in 2009. Przegl Epidemiol 2011;65(2):297-9 [in Polish].

70. Stępień M, Czarkowski MP. Hepatitis B in Poland in 2009. Przegl Epidemiol 2011;65(2):259-64 [in Polish].

71. Stępień M, Rosińska M. Studies on HCV infection prevalence in Poland - where are we? Przegl Epidemiol 2011;65(1):15-20, 21 ref. [in Polish].

72. Stypułkowska-Misiurewicz H, Czerwiński M. Legionellosis in Poland in 2009. Przegl Epidemiol 2011;65(2):219-21 [in Polish].

73. Szuba A, Martynowicz H, Zatońska K, Ilow R, Regulska-Ilow B, Różańska D, et al. Prevalence of hypertension in a sample of Polish population - baseline assessment from the prospective cohort 'PONS' study. Ann Agric Environ Med 2011;18(2):260-4, 27 ref.

74. Szyszkowicz M, Tremblay N. Case-crossover design: Air pollution and health outcomes. Int J Occup Med Environ Health 2011;24(3):249-55, 10 ref. DOI: 10.2478/ s13382-011-0034-y. 
75. Świątkowska B. Occupational factors influencing lung cancer in women in epidemiological studies. Med Pr 2011;62(6):659-65, 58 ref. [in Polish].

76. Wasiński B. Leptospirosis - current problems. Przegl Epidemiol 2011;65(3):471-6, 28 ref. [in Polish].

77. Wawrzyniak ZM, Paczesny D, Mańczuk M, Zatoński WA. Application of advanced data collection and quality assurance methods in open prospective study - A case study of PONS project. Ann Agric Environ Med 2011;18(2):207-14, 35 ref.

78. Werbińska-Sienkiewicz B, Rosińska M, Furman S. HIV and AIDS in Poland in 2009. Przegl Epidemiol 2011;65(2):289-95 [in Polish].

79. Wilczyńska U, Szeszenia-Dąbrowska N, Sobala W, Drożdż D. Occupational diseases in Poland, 2010. Med Pr 2011;62(4):347-57, 3 ref. [in Polish].

80. Włodarkiewicz A, Kozicka D, Michajłowski I, Sobjanek M, Niekra M, Nałęcz D. Skin cancer - epidemiological, clinical and surgical treatment analysis of 1406 patients. Przegl Dermatol 2011;98(2):104-11, 19 ref. [in Polish].

81. Wojtyła A. Differences in health - A global problem and its various aspects. Ann Agric Environ Med 2011;18(2):191-2, 25 ref.

82. Wojtyła A. Application of the hypothesis of Developmental Origin of Health and Diseases (DOHaD) in epidemiological studies of women at reproductive age and pregnant women in Poland. Ann Agric Environ Med 2011;18(2):355-64, 105 ref.

83. Wojtyła A, Kapka-Skrzypczak L, Biliński P, Paprzycki P. Physical activity among women at reproductive age and during pregnancy (Youth Behavioural Polish Survey - YBPS and Pregnancy-related Assessment Monitoring Survay - PrAMS) - epidemiological population studies in Poland during the period 2010-1011. Ann Agric Environ Med 2011;18(2):365-74, 85 ref.

84. Yusuf S. Case of the PONS study. Ann Agric Environ Med 2011;18(2):279-80, 5 ref.
85. Zagozdzon P, Kolarzyk E, Marcinkowski JT. Quality of life and rural place of residence in Polish women - population based study. Ann Agric Environ Med 2011;18(2):429-32, 20 ref.

86. Zatońska K, Ilow R, Regulska-Ilow B, Różańska D, Szuba A, Wołyniec M, et al. Prevalence of diabetes mellitus and IFG in the prospective cohort 'PONS' study - baseline assessment. Ann Agric Environ Med 2011;18(2):265-9, 19 ref.

87. Zatońska K, Janik-Koncewicz K, Ilow R, RegulskaIlow B, Różańska D, Szuba A, et al. Prevalence of obesity - baseline assessment in the prospective cohort 'PONS' study. Ann Agric Environ Med 2011;18(2): 246-50, 31 ref.

88. Zatoński WA. The PONS study and its place in the strategy of health gain in Poland. Ann Agric Environ Med 2011;18(2):193, 6 ref.

89. Zatoński WA. Epidemiological analysis of health situation development in Europe and its causes until 1990. Ann Agric Environ Med 2011;18(2):194-202, 23 ref.

90. Zatoński WA, Mańczuk M. POlish-Norwegian Study (PONS): research on chronic non-communicable diseases in European high risk countries - study design. Ann Agric Environ Med 2011;18(2):203-6, 1 ref.

91. Zatoński WA, Vatten L. Polish-Norwegian Study (PONS). Ann Agric Environ Med 2011;18(2):285, 2 ref.

92. Zemła B, Kołosza Z. Mortality trends for most common types of cancer in Silesia voivodeship in short term projection. Med Srod 2011;14(2):24-31, 17 ref. [in Polish]. 93. Zemła B, Kołosza Z. Thyroid cancer among Silesia females population. Med Srod 2011;14(2):39-44, 9 ref. [in Polish].

94. Zieliński A. Man and his environment from the perspective of epidemiologist. Przegl Epidemiol 2011;65(3): 393-9, 8 ref. [in Polish].

95. Zieliński A, Czarkowski MP. Infectious diseases in Poland in 2009. Przegl Epidemiol 2011;65(2):171-9 [in Polish]. 


\section{DIAGNOSTICS AND THERAPY OF ACUTE POISONING}

1. Antkowiak O, Brytan M, Zdanowski R, Kalinowski R. Contemporary capabilities of chemical warfare agent decontamination from the body surface. Lek Wojsk 2011;89(2):111-5, 31 ref. [in Polish].

2. Antkowiak O, Brytan M, Zdanowski R, Kalinowski R. Acetylcholinesterase enzyme reactivators in nerve agent poisoning. Lek Wojsk 2011;89(2):116-22, 64 ref. [in Polish].

3. Bąk M, Czerniak M, Kicińska-Krogulska M, Michowicz A, Krakowiak A. Toxic liver injuries - A current view on pathogenesis. Part I. Med Pr 2011;62(1):47-55, 73 ref. [in Polish].

4. Bąk M, Kicińska-Krogulska M, Czerniak P, Michowicz A, Krakowiak A. Toxic liver injuries - A current view on pathogenesis. Part II. Med Pr 2011;62(2): 203-10, 65 ref. [in Polish].

5. Epping G, van Baarlen J, van der Valk PDLPM. Toxic alveolitis after inhalation of a water repellent. Int J Occup Med Environ Health 2011;24(4):409-13, 17 ref. DOI: 10.2478/s13382-011-0038-7.

6. Krakowiak A, Kotwica M, Śliwkiewicz K, PiekarskaWijatkowska A. Epidemiology of acute poisonings during 2003-2007 in Toxicology Unit, Department of Occupational Medicine and Toxicology, Nofer Institute of Occupational Medicine, Łódź, Poland. Int J Occup Med Environ Health 2011;24(2):199-207, 15 ref. DOI: 10.2478/ s13382-011-0016-0.

7. Pawłowska-Kamieniak A, Mroczkowska-Juchkiewicz A, Gołyska D, Pac-Kożuchowska E. Causes of accidental poisonings in children treated in Paediatric Department between 1992-2002 and 2005-2009. Probl Hig Epidemiol 2011;92(3):688-91, 10 ref. [in Polish].

8. Pawłowska-Kamieniak A, Mroczkowska-Juchkiewicz A, Gołyska D, Pac-Kożuchowska E. Social and clinical aspects of childhood acute alcohol intoxication. Probl Hig Epidemiol 2011;92(3):692-4, 6 ref. [in Polish].
9. Skotnicka-Klonowicz G, Grochocińska P, Kuziemska A. Alcohol poisoning as a medical problem at the clinical ward of children's emergency medicine. Zdrow Publiczne 2011;121(1):12-5, 10 ref.

10. Żaba C, Marcinkowski JT, Wojtyła A, Tężyk A, Tobolski J, Żaba Z. Acute collective gas poisoning at work in a manure storage tank. Ann Agric Environ Med 2011;18(2):448-51, 25 ref.

\section{OCCUPATIONAL PHYSIOLOGY, PSYCHOLOGY, SOCIOLOGY AND ERGONOMICS}

1. Adamczyk JG, Boguszewski D, Debrzak-Adamczyk I, Ochal A. Physical activity and fitness of physiotherapists. Zdrow Publiczne 2011;121(4):344-9, 21 ref.

2. Aouil B, Leźnicka M, Jachimowicz-Wołoszynek D, Zaremba J. Occupational burnout syndrome - an attempt to assess the magnitude of the problem in the KujawskoPomorskie province. Probl Hig Epidemiol 2011;92(3): 436-40, 5 ref. [in Polish].

3. Basińska B, Wilczek-Rużyczka E. Burnout syndrome and fatigue in the context of shift work and occupational stress among surgery nurses. Przegl Psychol 2011;54(1): 101-14, 39 ref. [in Polish].

4. Basińska MA, Andruszkiewicz A, Grabowska M. Nurses' sense of coherence and their work related patterns of behaviour. Int J Occup Med Environ Health 2011;24(3): 256-66, 36 ref. DOI: 10.2478/S13382-011-0031-1.

5. Bednarek H. Analysis of efficiency of pilot's behavior in condition of visual illusion of false horizon. Stud Psychol 2011;49(1):5-20, 49 ref. [in Polish].

6. Bembnowska M, Jośko J. Depressive behaviors among adolescents as a public health problem. Zdrow Publiczne 2011;121(4):426-30, 17 ref. [in Polish].

7. Bertrandt J, Łakomy R, Kłos A. Energy expenditure of selected Polish Navy warship crews. Lek Wojsk 2011;89(1):36-9, 10 ref. [in Polish]. 
8. Biernacki M, Tarnowski A. The effect of age and personality on the main cognitive processes in drivers. Int J Occup Med Environ Health 2011;24(4):367-79, 50 ref. DOI: 10.2478/s13382-011-0035-x.

9. Bogdan A. Risk assessment in terms of heat stress in enclosed spaces. Bezpiecz Pr 2011;(3):7-10, 10 ref. [in Polish].

10. Bogdan A. Assessment of local thermal discomfort in offices. Bezpiecz Pr 2011;(7-8):24-6, 11 ref. [in Polish].

11. Bojar I, Humeniuk E, Owoc A, Wierzba W, Wojtyła A. Exposing women to workplace stress factors as a risk factor for developing arterial hypertension. Ann Agric Environ Med 2011;18(1):175-82, 44 ref.

12. Brzeźniak H, Rotter I, Żułtak-Bączkowska K, Jasińska M, Grochans E, Szych Z, et al. The influence of the chosen stress-inducing factors on the professional functioning of nurses depending on their age and job seniority. Zdrow Publiczne 2011;121(1):43-6, 12 ref.

13. Budziszewski P, Grabowski A, Jankowski J, Milanowicz M. Designing a workplace for workers with motion disability with computer simulation and virtual reality techniques. Bezpiecz Pr 2011;(5):6-8, 7 ref. [in Polish].

14. Bugajska J, Żołnierczyk-Zreda D, Hildt-Ciupińska K. Musculoskeletal ailments prophylaxis in the light of psychosocial work conditions. Bezpiecz Pr 2011;(4): 12-5, 10 ref. [in Polish].

15. Byra S, Parchomiuk M. Job satisfaction among disabled people with various levels of professional identification. Polit Społ 2011;38(4):20-6, 23 ref. [in Polish].

16. Chiba T, Ishii H, Takahashi S, Yano T. Relationship between blood lactate and hyperventilation during high-intensity constant-load exercise in heat. Biol Sport 2011;28(3):159-63, 20 ref.

17. Chmiel J, Chołuj K, Fijewski A, Majcher P. The analysis and comparison of Pilicz's test results as an evaluation of the physical fitness. Zdrow Publiczne 2011;121(1): 27-31, 10 ref.
18. Chrostowski K, Kwiatkowska D, Pokrywka A, Stańczyk D, Wójcikowska-Wójcik B, Grucza R. Renin-angiotensin-aldosterone system in bodybuilders using supraphysiological doses of anabolic-androgenic steroids. Biol Sport 2011;28(1):11-7, 47 ref.

19. Cięszczyk P, Eider J, Arczewska A, Ostanek M, Leońska-Duniec A, Sawczyn S, et al. The HIF1A gene Pro582Ser polymorphism in Polish power-orientated athletes. Biol Sport 2011;28(2):111-4, 19 ref.

20. Cukrowska L. Occupational risk resulting from psychosocial threats in customer service departments. Bezpiecz Pr 2011;(1):5-9, 8 ref. [in Polish].

21. Czaja J, Lebiedzińska A, Marszałł M, Szefer P. Evaluation for magnesium and vitamin B6 supplementation among Polish elite athletes. Rocz Panstw Zakl Hig 2011;62(4):413-8, 35 ref.

22. Derbis R, Baka $Ł$. The role of social support and work engagement in the work stressors-burnout relationship. Czas Psychol 2011;17(2):277-87, 53 ref. [in Polish].

23. Długołęcka B, Czeczelewski J, Raczyńska B. Bone mineral content and bone mineral density in female swimmers during the time of peak bone mass attainment. Biol Sport 2011;28(1):69-74, 40 ref.

24. Domańska I, Bawa S. The influence of nutritional intervention on resting energy expenditure in obese adolescents aged 15-18 years. Rocz Panstw Zakl Hig 2011;62(1): 65-9, 20 ref. [in Polish].

25. Drabek M, Andysz A. Effects of marijuana and amphetamine (and its derivatives) on driving performance based on the driving simulator studies. Med Pr 2011;62(5): 551-63, 32 ref. [in Polish].

26. Drobek-Słowik M, Karczewicz D. Visual ergonomics in work with the computer. Okulistyka 2011;(4): 82-4, 18 ref. [in Polish].

27. Dudek B, Hauk M, Merecz D. Assessment workaholism as a behavioral tendency: The Polish adaptation of the Mudrack and Naughton questionnaire. Med Pr 2011;62(2):127-32, 20 ref. [in Polish]. 
28. Dudek B, Szymczak W. The role of cognitive schemata in the development of posttraumatic stress disorder: results of cross-sectional and longitudinal studies. Int J Occup Med Environ Health 2011;24(1):29-35, 14 ref. DOI: 10.2478/s13382-011-0010-6.

29. Dziemidok P, Makara-Studzińska M, Jarosz MJ. Diabetes and depression: a combination of civilization and lifestyle diseases is more than simple problem adding - literature review. Ann Agric Environ Med 2011;18(2):31822, 76 ref.

30. Erenkfeit K, Dudzińska L, Indyk A. Mobbing in the workplace - description and effects. Med Srod 2011;14(4):81-9, 17 ref. [in Polish].

31. Franczuk M. Recognition of exercise-induced bronchoconstriction - A task for a medal. Pneumonol Alergol Pol 2011;79(6):379-81, 11 ref. [in Polish].

32. Gacek M. Selected health habits of the group of women in the rural and urban environment according to their socio-economic and nutritional status. Probl Hig Epidemiol 2011;92(2):260-6, 49 ref. [in Polish].

33. Gacek M, Chrzanowska M. Anthropometric indexes of the state of nutrition and eating habits, and recreational physical activity of working physically men aged 20-60 of urban population. Rocz Panstw Zakl Hig 2011;62(3):319-23, 20 ref. [in Polish].

34. Gacek M. Eating behaviors and physical activity in a group of physicians. Probl Hig Epidemiol 2011;92(2):254-9, 39 ref. [in Polish].

35. Gębska-Kuczerowska A, Wysocki MJ, Supranowicz P, Supranowicz T. Depression, overweight and perceived body image among adolescents living in suburban areas. Rocz Panstw Zakl Hig 2011;62(4):427-31, 18 ref. [in Polish].

36. Gierlotka S. The influence of lightening conditions on electrophysiological reaction in human skin. Pr Zdrow Bezpiecz 2011;(1):7-11, 6 ref. [in Polish].

37. Gierlotka S. The methods of testing a human body's impedance. Pr Zdrow Bezpiecz 2011;(3):6-9, 11 ref. [in Polish].
38. Głowacka MD, Kwapisz U, Frankowska A. Selected elements of life style and health issues of 50+ persons. Zdrow Publiczne 2011;121(2):135-40, 10 ref.

39. Groth J, Zaszczyk B. Comorbidity of posttraumatic stress disorder and mental disorders in British soldiers who served in Iraq and Afghanistan. Lek Wojsk 2011;89(3):209-17, 33 ref. [in Polish].

40. Grunt-Mejer K, Grunt-Mejer J. Road aggression - An underestimated hazard. Bezpiecz Pr 2011;(7-8):179, 15 ref. [in Polish].

41. Heszen I. Purposeful and reactive behaviors as complementary forms of coping with stress. Przegl Psychol 2011;54(1):47-66, 36 ref. [in Polish].

42. Hildebrand K. Exercise-induced bronchoconstriction. Pneumonol Alergol Pol 2011;79(1):39-47, 46 ref. [in Polish].

43. Hildebrand K, Przybyłowski T, Maskey-Warzęchowska M, Chazan R. Usefulness of selected tests in the diagnosis of exercise induced bronchoconstriction. Pneumonol Alergol Pol 2011;79(6):397-406, 30 ref. [in Polish].

44. Holdys J, Kryściak J, Stanisławski D, Gronek P. Polymorphism of the $\alpha$-ACTN3 gene in individuals practising different sports disciplines. Biol Sport 2011;28(2): 101-6, 20 ref.

45. Humeniuk E, Bojar I, Owoc A, Wojtyła A, Fronczak A. Psychosocial conditioning of depressive disorders in post-menopausal women. Ann Agric Environ Med 2011;18(2):441-5, 45 ref.

46. Hwang J, Kim YH. Adolescents' physical activity and its related cognitive and behavioural processes. Biol Sport 2011;28(1):19-22, 18 ref.

47. Ignac-Nowicka J, Dyas M. Working space assessment of the office workplaces using the checklist and Polish Standards. Pr Zdrow Bezpiecz 2011;(4):11-7, 11 ref. [in Polish].

48. Janosik E, Marzec S, Łaciak M, Nowicka J, Zachara J. Impact of energy-saving light sources on the efficiency and comfort vision of elderly people. Med Srod 2011;14(3):40-8, 9 ref. [in Polish]. 
49. Janosik E, Marzec S, Łaciak M, Nowicka J, Zachara J. The efficiency and comfort vision of young people in the energy-save light sources' lighting. Med Srod 2011;14(4):34-41, 11 ref. [in Polish].

50. Januszewicz A, Łuszczyńska A. Theory and practice: Applications of health behavior change models in obesity prevention programs for children and adolescents in Poland (years 2005-2009). Przegl Psychol 2011;54(1): 15-28, 21 ref. [in Polish].

51. Klimek AT, Lubkowska A, Szyguła Z, Frączek B, Chudecka M. The influence of single whole body cryostimulation treatment on the dynamics and the level of maximal anaerobic power. Int J Occup Med Environ Health 2011;24(2):184-91, 35 ref. DOI: 10.2478/ s13382-011-0017-z.

52. Kowalczuk K, Jankowiak B, Krajewska-Kułak E, Van Damme-Ostapowicz K, Kowalewska B. Comparison of the level of aggression towards healthcare workers within Podlaskie Voivodeship. Int J Occup Med Environ Health 2011;24(3):267-74, 24 ref. DOI: 10.2478/ s13382-011-0024-0.

53. Kucharska A, Sińska B, Zacharewicz K. The effects of shift work on health. Zdrow Publiczne 2011;121(4): 431-6, 15 ref. [in Polish].

54. Kułagowska E. Staff opinion on work arduousness in the Social Welfare Home. Med Srod 2011;14(4):5865, 9 ref. [in Polish].

55. Kurowska K, Wieczór-Klein K. Sense of coherence and styles of coping with stress in people with hearing impairment. Otorynolaryngologia 2011;10(1):42-8, 6 ref. [in Polish].

56. Lipińska-Grobelny A. Effects of gender role on personal resources and coping with stress. Int J Occup Med Environ Health 2011;24(1):18-28, 30 ref. DOI: 10.2478/ s13382-011-0002-6.

57. Lubrańska A. Organizational climate and burnout syndrome. Med Pr 2011;62(6):623-31, 24 ref. [in Polish].
58. Łagowska K, Woźniewicz M, Jeszka J. Comparison of eating habits among students with admitted sex and level of physical activity. Rocz Panstw Zakl Hig 2011;62(3):335-42, 19 ref. [in Polish].

59. Łuczak A, Tarnowski A. Professional drivers selection - positive or negative choice. Bezpiecz Pr 2011;(4): 9-11, 12 ref. [in Polish].

60. Makowiec-Dąbrowska T, Bortkiewicz A, Siedlecka J, Gadzicka E. Effect of fatigue on the fitness to drive. Med Pr 2011;62(3):281-90, 60 ref. [in Polish].

61. Marszałek A. A cold environment - its specificity and ways of protecting the human body against the adverse effects of the cold. Bezpiecz Pr 2011;(10):18-21, 13 ref. [in Polish].

62. Mazurek K, Żmijewski P, Czajkowska A, Lutosławska G. High-sensitivity C-reactive protein (hsCRP) in young adults: relation to aerobic capacity, physical activity and risk factors for cardiovascular diseases. Biol Sport 2011;28(4):227-32, 36 ref.

63. Merecz D, Andysz A. Person-organization fit and work ability. Med Pr 2011;62(3):247-58, 34 ref. [in Polish].

64. Mockało Z. The impact of leadership style on employees' mental wellbeing. Bezpiecz Pr 2011;(1):10-3, 9 ref. [in Polish].

65. Mroczkowska H. Accepted level of risk of doping use in the view of young athletes. Biol Sport 2011;28(3): 183-7, 11 ref.

66. Naghii MR, Aref MA, Almadadi M, Hedayati M. Effect of regular physical activity on non-lipid (novel) cardiovascular risk factors. Int J Occup Med Environ Health 2011;24(4):380-90, 46 ref. DOI: 10.2478/ s13382-011-0044-9.

67. Ogłodek E. Symptoms intensification of post-traumatic stress in individuals performing the job of a medical rescue worker. Med Srod 2011;14(3):54-8, 20 ref. [in Polish].

68. Olejarz P, Olchowik G. The role of computerized dynamic posturography in the diagnosis of balance disorders. 
Otorynolaryngologia 2011;10(3):103-10, 21 ref. [in Polish].

69. Otrębski W, Wiącek G. Diagnostics in the vocational rehabilitation of people with mental impairments - theoretical foundations for the construction of instruments. Przegl Psychol 2011;54(4):401-24, 59 ref. [in Polish].

70. Parr MK, Pokrywka A, Kwiatkowska D, Schanzer W. Ingestion of designer supplements produced positive doping cases unexpected by the athletes. Biol Sport 2011;28(3):153-7, 33 ref.

71. Pawlak A. Lighting system design for a computer workstation for eyesight impaired people. Bezpiecz Pr 2011;(6):11-4, 10 ref. [in Polish].

72. Pawłowska-Cyprysiak K. What the quality of life of people with physical disability depends on. Bezpiecz Pr 2011;(10):6-8, 10 ref. [in Polish].

73. Piotrowicz M, Cianciara D. Salutogenesis - new approach to health and disease. Przegl Epidemiol 2011;65(3):521-7, 25 ref. [in Polish].

74. Pokora I. Influence of exogenous heat loads on the blood antioxidant status in men consuming a normal-mixed diet. Probl Hig Epidemiol 2011;92(3):597-602, 31 ref. [in Polish].

75. Popiołek K, Wojtyna E. Survive between the devil and the deep sea. Personal and psycho-social predictors of work-family and family-work conflict among nurses. Czas Psychol 2011;17(1):97-106, 27 ref. [in Polish].

76. Popławska H, Dmitruk A, Hołub W, Wilczewski A. Relationship between underweight or overweight and the physical fitness of girls from Eastern Poland. Zdrow Publiczne 2011;121(1):22-6, 20 ref.

77. Poprawa R. Coping styles and the risk of alcohol problems among adolescents. Przegl Psychol 2011;54(1):6786, 40 ref. [in Polish].

78. Poprawa R. Test of problematic using of the Internet. Polish adaptation and validation of $K$. Young's Internet Addiction Test. Przegl Psychol 2011;54(2):193-216, 42 ref. [in Polish].
79. Potocka A, Mościcka A. Occupational stress, coping styles and eating habits among Polish employees. Med Pr 2011;62(4):377-88, 44 ref. [in Polish].

80. Pruszyński JJ, Gębska-Kuczerowska A, CichaMikołajczyk A, Gromulska L. Charakter of abuse towards the elderly through history. Przegl Epidemiol 2011;65(3):503-7, 16 ref.

81. Puchalski K, Korzeniowska E, Kaczanowska-Burker E, Kurkowska K. The evaluation of the KujawskoPomorski program of mental health promotion at work based on the institutions' self-assessment questionnaire: results of and experience gained from the first stage of implementation. Med Pr 2011;62(6):609-22, 16 ref. [in Polish].

82. Ratajska A, Szmaus-Jackowska A. Application of the Questionnaire of Self-concern and Concern in the rehabilitation of people with disabilities. Przegl Psychol 2011;54(4):383-400, 6 ref. [in Polish].

83. Saczuk J, Olszewska D, Wasiluk A, Olszewski J. Physical fitness of boys with overweight and obesity living in the eastern provinces of Poland. Zdrow Publiczne 2011;121(4):350-4, 15 ref.

84. Sękowski AE, Niziołek M. Determinants of attitudes towards people with various types of disabilities. Przegl Psychol 2011;54(4):343-61, 55 ref. [in Polish].

85. Siebert J, Zielińska D, Trzeciak B, Bakuła S. Haemodynamic response during exercise testing in patients with coronary artery disease undergoing a cardiac rehabilitation programme. Biol Sport 2011;28(3):189-93, 26 ref.

86. Stanina W, Krause M. The analysis of occupational stress for example of investment advisor. Pr Zdrow Bezpiecz 2011;(3):17-21, 14 ref. [in Polish].

87. Sobolewski A, Zwolińska M. Problems associated with assessing the thermal environment with the PMV index. Bezpiecz Pr 2011;(12):20-3, 8 ref. [in Polish].

88. Strzała M, Szyguła Z, Głąb G, Ostrowski A. Human organism functioning in high altitude. Med Srod 2011;14(4):90-7, 40 ref. [in Polish]. 
89. Świętochowski W. Professional burnout among university and high school teachers - comparative study. Med Pr 2011;62(2):133-43, 20 ref. [in Polish].

90. Taradejna B. Expectations motivating teachers to take up work in education. Bezpiecz Pr 2011;(12):24-7, 10 ref. [in Polish].

91. Trojanowska A. The role of a nurse in prevention of child abuse syndrome. Zdrow Publiczne 2011;121(2): 191-5, 23 ref. [in Polish].

92. Waszkowska M, Wagrowska-Koski E. Recommended general principles of good practice relating to psychological examinations in occupational medicine service. Med Pr 2011;62(5):527-36, 29 ref. [in Polish].

93. Wesołowski S, Boros P. Restrictive pattern in spirometry. Does FEV ${ }_{1} / F V C$ need to be increased? Pneumonol Alergol Pol 2011;79(6):382-7, 14 ref. [in Polish].

94. Wilski M. Self-care after myocardial infarction and its personal and social conditions. Przegl Psychol 2011;54(4):363-82, 52 ref. [in Polish].

95. Witanowska J, Obuchowicz A, Warmuz-Wancisiewicz A, Szczurek U. Assessment of nutritional status of selected group of children living in urban and rural areas in Upper Silesia, in the intervening five years. Int J Occup Med Environ Health 2011;24(2):177-83, 15 ref. DOI: 10.2478/s13382-011-0015-1.

96. Włodarczyk D, Tobolska B. Professional image of nurses as perceived by doctors, patients and nurses themselves. Med Pr 2011;62(3):269-79, 25 ref. [in Polish].

97. Włodarek D, Kuźnia A, Krusiec J, Tymolewska-Niebuda B. Assessment of energy balance between energy intake and expenditure of long-distance runners and the macronutrient contribution in the diet. Probl Hig Epidemiol 2011;92(3):594-6, 10 ref. [in Polish].

98. Worach-Kardas H, Kostrzewski S. Unemployment stress and quality of life of long-term unemployed in older age groups. Probl Hig Epidemiol 2011;92(3): 403-14, 49 ref. [in Polish].
99. Woźniak M. Alternative way of long-term unemployed reintegration. Polit Spol 2011;38(10):16-22, 32 ref. [in Polish].

100. Zeidler W. Life satisfaction: Inspirations and attempts to conceptualization. Przegl Psychol 2011;54(4): 323-42, 50 ref. [in Polish].

101. Zwiech P. Kinds of gender discrimination on the labour market. Polit Społ 2011;38(4):17-20, 19 ref. [in Polish].

102. Zwierko T, Lubiński W, Czepita D. Effect of physical exercise with increasing intensity on electroretinographic oscillatory potentials. Okulistyka 2011;(4): 13-6, 20 ref. [in Polish].

\section{THE OCCUPATIONAL HEALTH CARE SYSTEM}

1. Antoniak M. Working conditions in Poland against a background of other EU member states - European Working Conditions Survey results. Bezpiecz Pr 2011;(9): 26-8, 8 ref. [in Polish].

2. Arandjelovic M. A need for holistic approach to the occupational health developing (in Serbia). Int J Occup Med Environ Health 2011;24(3):229-40, 67 ref. DOI: 10.2478/s13382-011-0033-Z.

3. Bajon W. Structure and functions of a logistics management infrastructure as a basis for determining occupational threats throughout its exploitation. Bezpiecz Pr 2011;(12):7-9, 6 ref. [in Polish].

4. Bergier J, Dąbrowski D, Żbikowski J. Conditioning of participation of disabled males and females from eastern regions of Poland in tourism and recreation. Ann Agric Environ Med 2011;18(2):350-4, 30 ref.

5. Bracław M, Górniak K. Health status of University students in the light of the research carried out in Poland in years 19702010. Zdrow Publiczne 2011;121(4):338-43, 27 ref.

6. Broszkiewicz R, Gajek A. Chosen problems of Polish legislation on transport of dangerous materials. Bezpiecz Pr 2011;(11):24-5, 15 ref. [in Polish]. 
7. Buczak-Stec E, Lemanowicz K, Mazurek M. E-healthchallenge for health care system. Przegl Epidemiol 2011;65(1):107-14, 25 ref. [in Polish].

8. Chałas R, Bachanek T, Cieszko-Buk M, WójcikChęcińska I. The image of dentist profession in the opinion of dentistry students of the Medical University of Lublin in 2004-2007. Zdrow Publiczne 2011;121(2): 147-50, 12 ref.

9. Chmielewski J. The premises of refraining from work in the aspects of industrial safety. Pr Zdrow Bezpiecz 2011;(3):24-9, 4 ref. [in Polish].

10. Cianciara D. Three decades of health promotion - time to act. Probl Hig Epidemiol 2011;92(1):7-13, 32 ref. [in Polish].

11. Cianciara D. Public health in Poland before world war II - lesson learned. Przegl Epidemiol 2011;65(4): 635-41, 29 ref. [in Polish].

12. Cianciara D, Wysocki MJ. Position of health at international relations. Part I. Structural dimensions of health. Przegl Epidemiol 2011;65(2):371-7, 25 ref. [in Polish].

13. Cianciara D, Wysocki MJ. Position of health at international relations. Part II. Organizational dimensions of health. Przegl Epidemiol 2011;65(2):379-87, 23 ref. [in Polish].

14. Cichońska D, Iltchev P. Risk management in health care centres. Zdrow Publiczne 2011;121(1):3-7, 13 ref.

15. Dąbrowski A, Zamojski A. Accidents in small construction enterprises. Bezpiecz Pr 2011;(11):6-9, 14 ref. [in Polish].

16. Derkacz M, Chmiel-Perzyńska I, Buczak-Stec E, Pachuta I, Kowal A, Grywalska E, et al. Co-payment for public health care services - public opinion survey. Przegl Epidemiol 2011;65(2):363-70, 10 ref. [in Polish].

17. Dyląg W. Occupational safety and health of employees over borders. Bezpiecz Pr 2011;(2):20-2, 15 ref. [in Polish].

18. Dziedzic A. An ability to bring first aid among drivers participating in the event called "Do not be afraid to save others' lives!". Bezpiecz Pr 2011;(3):22-5, 4 ref. [in Polish].

19. Farin K. Social media and their impact on OSH communication. Bezpiecz Pr 2011;(9):22-4, 12 ref. [in Polish].

20. Furtak M, Książek P, Warchoł-Sławińska E, Drop B, Włoch K, Kulbaka E. Development of the health care market - forecasts for the future. Zdrow Publiczne 2011;121(1):76-80, 4 ref.

21. Furtak M, Książek P, Warchoł-Sławińska E. The process of decision-making in the health care sector. Zdrow Publiczne 2011;121(3):228-33, 15 ref.

22. Garus-Pakowska A, Pakowski M. Elements of state coercion in health care: selected issues. Med Pr 2011;62(1):67-72, 7 ref. [in Polish].

23. Gawron-Skarbek A, Nowacka E, Laszek M, Szatko F. Negative behavior patterns of students. Part III. Complying with hygienic rules of working in contact with infectious material. Probl Hig Epidemiol 2011;92(3):46673, 14 ref. [in Polish].

24. Gembalska-Kwiecien A. Are trainings from the range of safety and the hygiene of work the according to workers necessary? Pr Zdrow Bezpiecz 2011;(3):1-6, 7 ref. [in Polish].

25. Gotlib J, Białoszewski D, Lewandowska M. Interprofessional education in medical professions - does it make sense? Review of the literature. Zdrow Publiczne 2011;121(3):288-94, 37 ref. [in Polish].

26. Gromulska L, Gajewska M. Cooperation in health behaviour change programmes. An example of nutrition in adolescents. Przegl Epidemiol 2011;65(1):15965, 8 ref. [in Polish].

27. Gromysz-Kałkowska K, Unkiewicz-Winiarczyk A, Szubartowska E. The problem of tobacco smoking among high school students under the survey research. Zdrow Publiczne 2011;121(4):332-7, 18 ref.

28. Hildt-Ciupińska K, Bugajska J. The role of pro-health behaviors in promoting workers' health. Bezpiecz Pr 2011;(9):10-3, 14 ref. [in Polish]. 
29. Hoffmann K, Bryl W, Marcinkowski JT, Strażyńska A, Pupek-Musialik D. Estimation of physical activity and prevalence of excessive body mass in rural and urban Polish adolescents. Ann Agric Environ Med 2011;18(2):398-403, 21 ref.

30. Hot I, Karlikaya E, Sarper Erdogan M. Survey of the opinions on the occupational health system in Turkey expressed by patients of the Istanbul Hospital of Occupational Diseases. Int J Occup Med Environ Health 2011;24(2):192-8, 35 ref. DOI: 10.2478/s13382011-0014-2.

31. Ignac-Nowicka J, Białas K. Safety monitoring system in the process of acetylene production. Pr Zdrow Bezpiecz 2011;(3):9-16, 11 ref. [in Polish].

32. Irzmańska E, Majchrzycka K, Stefko A. Evaluating proper selection of protective gloves for work involving hand knives - on the basis of questionnaire surveys. Bezpiecz Pr 2011;(9):14-7, 12 ref. [in Polish].

33. Jahnz-Różyk K, Targowski T, From S, Faluta T, Borowiec Ł. Costs of chronic obstructive pulmonary disease in patients treated in ambulatory care in Poland. Pneumonol Alergol Pol 2011;79(5):337-42, 30 ref. [in Polish].

34. Janaszczyk A, Bogusz-Czerniewicz M, Malicki J. The comparison of qualifications, skills and professional competences between radiologic technologists in Poland and selected EU countries. Zdrow Publiczne 2011;121(4):401-6, 15 ref.

35. Jośko J, Kasperczyk J, Grzybowski A, Ejsmont J, Karwat D, Zarzeczna-Baran M, et al. Career plans of Polish medical university students. Probl Hig Epidemiol 2011;92(2):199-203, 11 ref.

36. Jurek $€$. Changes of the pension system in the age of population aging. Polit Spol 2011;38(11-12):4-9, 14 ref. [in Polish].

37. Jurkiewicz M, Mianowana V, Wysokiński A. Tobacco addiction among patients after myocardial infarction. Zdrow Publiczne 2011;121(4):328-31, 13 ref.
38. Kalina-Prasznic U. Retirement risks and neglected patterns of social protection. Polit Spol 2011;38(4): 7-11, 6 ref. [in Polish].

39. Kamińska MS, Dąbrowska O, Baranowska E, Rotter I, Rozkrut M. Comparative analysis of health risk behaviours demonstrated by law students of the University of Szczecin in Poland and the University of Lund in Sweden. Zdrow Publiczne 2011;121(2):151-6, 15 ref.

40. Kamusińska E, Lelonek B. Analysis of leisure activities for disabled people aged 65 as a basis for planning health education diagnosis. Zdrow Publiczne 2011;121(4):382-7, 11 ref.

41. Kapka-Skrzypczak L, Cyranka M, Wojtyła A. Legal highs as an urgent issue of public health. Zdrow Publiczne 2011;121(2):174-80, 26 ref. [in Polish].

42. Kapka-Skrzypczak L, Kulpa P, Sawicki K, Cyranka M, Wojtyła A, Kruszewski M. Legal highs - legal aspects and legislative solutions. Ann Agric Environ Med 2011;18(2):304-9, 38 ref.

43. Kłos A, Bertrandt J. Overweight and obesity occurrence and estimation of mineral nutritional status of military medical aircraft crews. Lek Wojsk 2011;89(2): 93-7, 25 ref. [in Polish].

44. Kłos A, Bertrandt J, Dębski B. Overweight and obesity among first-year students of Public Health at the Maria Skłodowska-Curie Warsaw Academy. Probl Hig Epidemiol 2011;92(3):636-9, 17 ref. [in Polish].

45. Kołaczek B. On the model of social policy aimed at disabled people. Theory and Polish practice. Polit Spol 2011;38(9):8-12, 17 ref. [in Polish].

46. Kołłątaj W, Sygit K, Sygit M, Karwat ID, Kołłątaj B. Eating habits of children and adolescents from rural regions depending on gender, education, and economic status of parents. Ann Agric Environ Med 2011;18(2):393-7, 26 ref.

47. Korzeniewski K, Pieniuta S, Nowak B, Wawreszuk M, Brzozowski R, Gregulski R. Tasks and structure of the health service of the Polish Military Contingent in Afghanistan. Lek Wojsk 2011;89(4):364-75, 10 ref. [in Polish]. 
48. Korzeniewski K. Preventive medicine activities during overseas military operations. Lek Wojsk 2011;89(4): 376-84, 29 ref. [in Polish].

49. Krause M. Organization of occupational risk assessment by Polish standards of PN-N-18002:2011. Pr Zdrow Bezpiecz 2011;(4):17-20, 13 ref. [in Polish].

50. Krawczyk A, Lada-Tondyra E. Electromagnetic fields in medicine - the history of the first experiments. Bezpiecz Pr 2011;(1):24-6, 4 ref. [in Polish].

51. Krzyśków B. Occupational safety and health of temporary workers - de lege ferenda remarks. Bezpiecz Pr 2011;(7-8):27-31, 11 ref. [in Polish].

52. Książek P, Drop B, Furtak M, Warchoł-Sławińska E. Digital Hospitals. How to navigate them? Zdrow Publiczne 2011;121(1):71-5, 5 ref.

53. Kułagowska E, Kosińska M, Nowak-Kapusta Z. Home long-term care in Poland. Med Srod 2011;14(2): 64-9, 11 ref. [in Polish].

54. Kułak A, Shpakov A, Kułak P. Preliminary analysis of the problem of nicotine, alcohol and drug addictions in the student population. Probl Hig Epidemiol 2011;92(1):137-45, 17 ref. [in Polish].

55. Kuziemski A, Czerniak B, Frankowska K, Gonia E, Korzycka-Wilińska W, Popow A. Score method evaluation of the sanitary condition of the University Hospital in Bydgoszcz and personnel education in 20072010. Przegl Epidemiol 2011;65(4):675-9, 9 ref. [in Polish].

56. Lachowski S, Zagórski J. Child labour for the benefit of the family in rural Poland. Ann Agric Environ Med 2011;18(2):386-92, 23 ref.

57. Lesińska-Sawicka M. Pregnancy planning and substance abuse during pregnancy by women in selected European countries. Probl Hig Epidemiol 2011;92(1): 127-31, 27 ref. [in Polish].

58. Lewandowska H. Risk management in a health care organization. Zdrow Publiczne 2011;121(3): 277-82, 15 ref. [in Polish].
59. Lewtak K, Smolińska J. Generalized self-efficacy in relation to anti-health behaviours of general practitioners exemplified by smoking. Przegl Epidemiol 2011;65(1):115-21, 27 ref. [in Polish].

60. Łaszek M, Nowacka E, Gawron-Skarbek A, Szatko F. Negative behavior patterns of students. Part II. Physical activity and eating habits. Probl Hig Epidemiol 2011;92(3):461-5, 13 ref. [in Polish].

61. Łaszek M, Nowacka E, Szatko F. Negative behavior patterns of students. Part I. Consumption of alcohol and use of psychoactive substances. Probl Hig Epidemiol 2011;92(1):114-9, 11 ref. [in Polish].

62. Łepecka-Klusek C, Pilewska-Kozak AB, Kołodziejczyk T, Pilewski BD, Jakiel G. Female attitudes towards the idea of co-participation in the costs of hospital treatment. Zdrow Publiczne 2011;121(4):355-9, 25 ref.

63. Łuczak A. Occupational safety in road traffic - an European perspective. Bezpiecz Pr 2011;(6):15-9, 16 ref. [in Polish].

64. Makuch K, Galus K. Influence of health and social conditions on seeking employment in retirement age. Probl Hig Epidemiol 2011;92(2):355-60, 7 ref. [in Polish].

65. Matuszek B, Zakościelna K, Baszak-Radomańska E, Pyzik A, Nowakowski A. Universal screening as a recommendation for thyroid tests in pregnant women. Ann Agric Environ Med 2011;18(2):375-9, 21 ref.

66. Michalik JS, Gajek A, Słomka L. Major accidents in road transport of dangerous materials (1) - predicting consequences. Bezpiecz Pr 2011;(3):15-8, 4 ref. [in Polish].

67. Michalik JS, Gajek A, Słomka L. Major accidents in road transport of dangerous materials (2) - assessing consequences. Bezpiecz Pr 2011;(4):6-8, 4 ref. [in Polish].

68. Michalik JS, Gajek A, Janik P, Zając S, Koniuch A, Obolewicz A, et al. Proposals for improvement of safety management in the cycle of road transport of dangerous goods. Bezpiecz Pr 2011;(5):24-7, 13 ref. [in Polish]. 
69. Milanowicz M, Budziszewski P. The use of computer simulation in reconstructing accidents at work. Bezpiecz Pr 2011;(3):4-6, 5 ref. [in Polish].

70. Miranowicz-Dzierżawska K. CLP regulation - harmonized classification, labelling and packaging of chemicals. Bezpiecz Pr 2011;(2):16-9, 6 ref. [in Polish].

71. Mirski T, Bartoszcze M, Bielawska-Drózd A. Globalization and infectious diseases. Przegl Epidemiol 2011;65(4):649-55, 27 ref. [in Polish].

72. Namysł A, Pawłowska-Cyprysiak K, Malińska M, Bugajska J. A young worker - A safe start at work. Bezpiecz Pr 2011;(10):22-5, 13 ref. [in Polish].

73. Naruszewicz-Lesiuk D, Magdzik W, Seroka D. Department of Epidemiology of the National Institute of Hygiene in Warsaw in the years 1951-2011 - origins of forming, developmental ways in 60 years of work. Przegl Epidemiol 2011;65(4):687-96. [in Polish].

74. Nowakowska-Głąb A, Maniecka-Bryła I. Relation between occupation and health related quality of life of pregnant women. Med Pr 2011;62(6):601-7, 23 ref. [in Polish].

75. Okręlicka M. Return to work management of people with temporary disability. Med Pr 2011;62(4): 445-52, 48 ref. [in Polish].

76. Olejniczak D. Implementation of European Union funds in health promotion on metropolitan city of Warsaw basing on HEPRO Project. Zdrow Publiczne 2011;121(4):323-7, 9 ref.

77. Ordysiński S. Analysis of chosen statistic data on accidents at work. Bezpiecz Pr 2011;(12):32-5, 6 ref. [in Polish].

78. Patryn R, Jarosz MJ, Włoszczak-Szubzda A, Sak J, Pawlikowski J. Considerations on Directive 98/8 of the European Commission - The biocide directive. Ann Agric Environ Med 2011;18(2):452-8, 30 ref.

79. Pawłowska Z. Impact of social responsibility rules enforcement on the quality of life at work. Bezpiecz Pr 2011;(4):16-8, 7 ref. [in Polish].
80. Pawłowska Z. EU strategy for OSH - evaluation of Scoreboard results. Bezpiecz Pr 2011;(6):20-3, 5 ref. [in Polish].

81. Petelczyc J. Farmers' social security system in Poland. University debate. Polit Spol 2011;38(11-12):30-2 [in Polish].

82. Pęciłło M. Effectiveness of programs dedicated to modifying unsafe behaviors in Polish enterprises. Bezpiecz Pr 2011;(5):9-11, 8 ref. [in Polish].

83. Pietraszkiewicz T. Roma children's health - The important problem of environmental medicine. Med Srod 2011;14(2):7-10, 24 ref. [in Polish].

84. Piętka M. Programs and IT tools for personal protective equipment. Bezpiecz Pr 2011;(1):22-3, 4 ref. [in Polish].

85. Puciato D, Łoś A. Patent protection for medicinal products - The negative aspects, alternatives. Zdrow $\mathrm{Pu}$ bliczne 2011;121(2):202-6, 15 ref. [in Polish].

86. Ridan T, Ślęczkowska J, Sobota M, Ochałek K. Evaluation of breast cancer prevention and quality of life by women after single breast mastectomy, grouped in the 'Amazons' postmastectomy women's club. Zdrow Publiczne 2011;121(1):32-6, 12 ref.

87. Rudnicka-Drożak E, Aftyka A. Alcohol abuse being the cause of medical emergency teams intervention. Zdrow Publiczne 2011;121(3):238-41, 11 ref.

88. Ruszkowska J. Decreasing social inequalities as a new priority in health promotion - the latest European and global tendency. Polit Spol 2011;38(10):8-11, 28 ref. [in Polish].

89. Rybarczyk A, Marczak M. Quality assessment of health care services in patients' and medical staff's opinion. Zdrow Publiczne 2011;121(2):111-6, 11 ref.

90. Rydlewska-Liszkowska I. Occupational health protection in business economics - business plan for health intervention. Med Pr 2011;62(5):481-8, 19 ref. [in Polish].

91. Sienkiewicz E, Szymańska J. Disability - definition and classification. Zdrow Publiczne 2011;121(4): 412-6, 20 ref. [in Polish]. 
92. Siermontowski P, Laskowska A, Olszański R. Professional preparation of mid-level medical personnel to give first aid in case of chemical disasters. Probl Hig Epidemiol 2011;92(2):211-5, 10 ref. [in Polish].

93. Skalski M, Jankowski A, Abramowicz J. Second level of medical treatment - the review of needs in the range of medical protection during combat action. Lek Wojsk 2011;89(1):56-9, 9 ref. [in Polish].

94. Stankiewicz-Choroszucha B, Samoliński B. Academic education in public health. Zdrow Publiczne 2011;121(2):212-7, 9 ref. [in Polish].

95. Sygit K, Kołłątaj W, Sygit M, Kołłątaj B. The impact of economic factors on the realities of outpatient multidrug treatment of chronic diseases in rural areas. Ann Agric Environ Med 2011;18(1):29-34, 25 ref.

96. Sygit K, Kołlątaj W, Wojtyła A, Sygit M, Bojar I, Owoc A. Engagement in risky behaviours by 15-19-yearolds from Polish urban and rural areas. Ann Agric Environ Med 2011;18(2):404-9, 25 ref.

97. Szczeniowski A, Gańczak M. The implementation of legislation acts regarding prevention of occupational exposure to bloodborne pathogens from perspective of Poland as the UE country. Med Pr 2011;62(1): 57-66, 27 ref. [in Polish].

98. Szczygielska A. Cognitive, social and behavioral approach towards attitude modification in view of the occupational safety. Bezpiecz Pr 2011;(4):19-21, 13 ref. [in Polish].

99. Szczygielska A. A behavioral approach to changing attitudes towards safety. Bezpiecz Pr 2011;(10): 26-9, 15 ref. [in Polish].

100. Szybkie A. The Polish-Canadian agreement on social security. Polit Społ 2011;38(2):26-32, 27 ref. [in Polish].

101. Trojanowska A. The significance of research in quality of life in medicine. Zdrow Publiczne 2011;121(1): 99-103, 30 ref. [in Polish].
102. Uścińska G. Additional pension schemes the EU regulations. Implication for the European countries. Polit Społ 2011;38(9):1-7, 13 ref. [in Polish].

103. Vanderwal L, Rautiainen R, Ramirez M, Kuye R, Peek-Asa C, Cook T, et al. Participatory approach to identify interventions to improve the health, safety, and work productivity of smallholder women vegetable farmers in the Gambia. Int J Occup Med Environ Health 2011;24(1):36-47, 29 ref. DOI: 10.2478/ s13382-011-0008-0.

104. Wojda M. Structure of human resources and activities of occupational medicine service in Poland in 2009 and dynamics and trends in recent years. Med Pr 2011;62(4):389-94, 9 ref. [in Polish].

105. Wojtyła A, Bojar I, Boyle P, Zatoński W, Marcinkowski JT, Biliński P. Nutritional behaviours among pregnant women from rural and urban environments in Poland. Ann Agric Environ Med 2011;18(1):169-74, 24 ref.

106. Wojtyła C, Biliński P, Paprzycki P, Warzocha K. Haematological parameters in postpartum women and their babies in Poland - comparison of urban and rural areas. Przegl Epidemiol 2011;65(1):147-52, 26 ref. [in Polish].

107. Wrona W, Hermanowski T, Jakubczyk M, Golicki D, Czech M, Niewada M, et al. Cost of lost productivity in pharmacoeconomics analysis. Part II. Survey in the expert group. Przegl Epidemiol 2011;65(1):153-7, 8 ref. [in Polish].

108. Wrońska B. Conscious family planning among women living the Łódź area, including their education and nature of work. Med Pr 2011;62(6):591-9, 18 ref. [in Polish].

109. Zadarko-Domaradzka M, Tlałka E, Sobolewski M. The implementation of the anticancer recommendations by professionally active women. Zdrow Publiczne 2011;121(3):267-71, 11 ref.

110. Zdunek K, Kulik TB, Janiszewska M, Bogusz R. Health and European Union. European Union 
and globalization. Zdrow Publiczne 2011;121(3): 283-7, 14 ref. [in Polish].

111. Zieliński A. Cost analysis of adjustments of the epidemiological surveillance system to mass gatherings. Przegl Epidemiol 2011;65(1):5-8, 7 ref.

112. Zieliński J. What do patients with chronic obstructive pulmonary disease die from? Pneumonol Alergol Pol 2011;79(5):317-9, 23 ref. [in Polish].

\section{ENVIRONMENTAL HAZARDS}

1. Bartosik K, Sitarz M, Szymańska J, Buczek A. Tick bites on humans in the agricultural and recreational areas in south-eastern Poland. Ann Agric Environ Med 2011;18(1):151-7, 83 ref.

2. Bartosik K, Szymańska J, Buczek A. Risk to human health posed by Ixodes ricinus ticks in relation to diagnostic and therapeutic possibilities in south-eastern Poland. Zdrow Publiczne 2011;121(3):263-6, 15 ref.

3. Bartosik K, Wiśniowski Ł, Buczek A. Abundance and seasonal activity of adult Dermacentor reticulatus (Acari: Amblyommidae) in eastern Poland in relation to meteorological conditions and the photoperiod. Ann Agric Environ Med 2011;18(2):340-4, 64 ref.

4. Błoniarz J, Zaręba S. The study of nickel and chromium contents in dietary supplements supporting slimming. Rocz Panstw Zakl Hig 2011;62(2):153-8, 23 ref. [in Polish].

5. Boberg E, Lessner L, Carpenter DO. The role of residence near hazardous waste sites containing benzene in the development of hematologic cancers in upstate New York. Int J Occup Med Environ Health 2011;24(4):327-38, 46 ref. DOI: 10.2478/ s13382-011-0037-8.

6. Buczek A, Bartosik K. Ticks (Ixodida: Ixodidae, Amblyommidae) in south-eastern Poland and their medical and epidemiological importance. Zdrow Publiczne 2011;121(4):392-7, 35 ref.
7. Buczek A, Bartosik K, Szymańska J, Buczek S. Pigeon tick Argas reflexus (Ixodida: Argasidae) in south-eastern Poland - biological features and clinical symptoms. Zdrow Publiczne 2011;121(4):422-5, 33 ref. [in Polish].

8. Chmielewski T, Andrzejewski K, Mączka I, Fiecek B, Radlińska M, Tylewska-Wierzbanowska S. Ticks infected with bacteria pathogenic to humans in municipal parks in Warsaw. Przegl Epidemiol 2011;65(4): 577-81, 25 ref. [in Polish].

9. Cielecka E, Dereń K. Food quality for infants and young children. Probl Hig Epidemiol 2011;92(2): 187-92, 23 ref. [in Polish].

10. Ćwiek-Ludwicka K, Pawlicka M, Starski A, Półtorak $\mathrm{H}$, Karłowski K. Studies on primary aromatic amines (PAAs) migration from multi-layer plastic food packaging by HPLC method. Rocz Panstw Zakl Hig 2011;62(4):371-5, 12 ref. [in Polish].

11. Frączek K, Górny RL. Microbial air quality at Szczawnica sanatorium, Poland. Ann Agric Environ Med 2011;18(1):63-71, 67 ref.

12. Gertig H, Stelmach-Mardas M. Safety of traditional food. Probl Hig Epidemiol 2011;92(3):387-91, 14 ref. [in Polish].

13. Głowacka A, Skoczylas P, Mianowany M, BednarekGejo A. Assessment of knowledge and awareness of the waste electrical and electronic equipment among the higher school students. Zdrow Publiczne 2011;121(3):2 58-62, 15 ref.

14. Gryz K, Karpowicz J, Zradziński P. Magnetic fields in buildings with electrical power equipment - preventive recommendations on reducing long-lasting exposure. Bezpiecz Pr 2011;(5):16-9, 17 ref. [in Polish].

15. Grzesik J. Fukushima - 25 years after Chernobyl. Med Srod 2011;14(4):9-19, 18 ref. [in Polish].

16. Hernik A, Góralczyk K, Struciński P, Czaja K, Kucharska A, Korcz W, et al. Polybrominated diphenyl ethers, polychlorinated biphenyls and organochlorine pesticides in human milk as markers of environmental 
exposure to these compounds. Ann Agric Environ Med 2011;18(1):113-8, 37 ref.

17. Jakubowski M. Low-level environmental lead exposure and intellectual impairment in children - the current concepts of risk assessment. Int J Occup Med Environ Health 2011;24(1):1-7, 22 ref. DOI: 10.2478/s13382011-0009-z.

18. Kanclerski K, Rohm-Rodowald E, Jakimiak B, Chojecka A, Jakubiec K. Waste generated in Polish hospitals during the years 2005-2009. Przegl Epidemiol 2011;65(4):681-6, 21 ref. [in Polish].

19. Kostka G, Urbanek-Olejnik K, Liszewska M. Risk assessment for cumulative exposure to pesticide residues in food. Rocz Panstw Zakl Hig 2011;62(2):127-36, 21 ref. [in Polish].

20. Kotłowski A, Kowalewska B, Rudzińska M. Toxocara eggs in children kindergartens in tri-city area and evaluation of interdependence quantification of invasion with frequency of antibodies incidence among population under study. Med Srod 2011;14(2):45-50, 30 ref. [in Polish].

21. Kozłowska A, Pawlas N, Zaciera M, Kapka-Skrzypczak L, Jasiński R. Polycyclic aromatic hydrocarbons concentration and mutagenic effects of dust in outdoor environment in Silesian Region. Med Srod 2011;14(3): 28-39, 59 ref. [in Polish].

22. Kucharska A, Góralczyk K, Czaja K, Struciński P, Hernik A, Korcz W, et al. Ubiquitous perfluorinated compounds. Rocz Panstw Zakl Hig 2011;62(2): 137-44, 51 ref. [in Polish].

23. Ledzion E, Rybińska K, Postupolski J, KurpińskaJaworska J, Szczęsna M. Studies and safety evaluation of aflatoxins in herbal plants. Rocz Panstw Zakl Hig 2011;62(4):377-81, 24 ref. [in Polish].

24. Leońska-Duniec A. Free-living amoebae as vectors of pathogenic microorganisms. Probl Hig Epidemiol 2011;92(2):173-80, 104 ref. [in Polish].
25. Matuszewska R, Krogulska B. Health risk for children resulting from Legionella occurrence in water network of children's wards in hospitals. Med Srod 2011;14(2): 51-6, 22 ref. [in Polish].

26. Michalska M, Bartoszewicz M, Cieszyńska M, Nowacki J. Marine bioaerosol in the area of Gdańsk Bay. Med Srod 2011;14(1):24-8, 11 ref. [in Polish].

27. Mojska H, Gielecińska I, Stoś K, Jarosz M. Acrylamide content in food in Poland in the light of current EU recommendations. Probl Hig Epidemiol 2011;92(3):6258, 18 ref. [in Polish].

28. Moshammer H, Wallner P. Air quality as respiratory health indicator - A critical review. Int J Occup Med Environ Health 2011;24(3):241-8, 26 ref. DOI: 10.2478/ s13382-011-0028-9.

29. Moździerz A, Juszko-Piekut M, Stojko J. Concentration levels of BaP in outdoor air of Upper Silesia towns in the years 1983-2005. Med Srod 2011;14(2):15-23, 34 ref. [in Polish].

30. Muhlendahl KE. Pediatric environmental medicine: Whence and where to? Med Srod 2011;14(4):7-8.

31. Muhlendahl KE, Otto M, Bose-O'Reilly S, Heudorf U, Lob-Corzilius T, Schmidt S. Leukaemia in children under 5 years in the close vicinity of nuclear power plants. Med Srod 2011;14(1):13-7, 20 ref.

32. Muhlendahl KE, Otto M, Linnemann J. How to explain the importance of human biomonitoring. Med Srod 2011;14(2):11-4, 3 ref.

33. Nazimek T, Wasak M, Zgrajka W, Turski WA. Content of transfluthrin in indoor air during the use of electro-vaporizers. Ann Agric Environ Med 2011;18(1): 85-8, 16 ref.

34. Olszewski J, Skubalski J. Radon concentrations in selected residential buildings in the city of Łódź. Med Pr 2011;62(1):31-6, 7 ref. [in Polish].

35. Pawlas K, Pawlas N. Wind farm, health effects. Pr Zdrow Bezpiecz 2011;(4):23-6, 26 ref. [in Polish]. 
36. Perez-Badia R, Rapp A, Vaquero C, FernandezGonzalez F. Aerobiological study in east-central Iberian Peninsula: pollen diversity and dynamics for major taxa. Ann Agric Environ Med 2011;18(1):99-111, 61 ref.

37. Posłuszny P, Fugiel J, Pokrywka J. Trends in body weight for 7-year boys from different environmental sites of Copper Mining Region. Med Srod 2011;14(4):49-57, 34 ref. [in Polish].

38. Sawilska-Rautenstrauch D, Gawarska H, Karłowski K. Analysis of notifications on exceeding of the acceptable level of histamine according to the RASFF reports. Rocz Panstw Zakl Hig 2011;62(4):365-9, 19 ref. [in Polish].

39. Sąkol G, Ochota P, Mirosławski J, Brewczyński PZ. Suitability of three cultivars of coral bells (Heuchera cvs.) to bioremediation of cadmium $(\mathrm{Cd})$, lead $(\mathrm{Pb})$ and zinc (Zn) from post-mining area in Zagłębie Dąbrowskie. Med Srod 2011;14(3):17-27, 24 ref. [in Polish].

40. Sicińska E, Wyka J. Folate intake in Poland on the basis of literature from the last ten years (2000-2010). Rocz Panstw Zakl Hig 2011;62(3):247-56, 70 ref. [in Polish]. 41. Snopczyński T, Struciński P, Góralczyk K, Czaja K, Hernik A, Korcz W, et al. Application of the QuEChERS method coupled with gas chromatography with electron capture detection (GC-ECD) in analysis of pesticide residues in food. Rocz Panstw Zakl Hig 2011;62(2): 145-51, 24 ref. [in Polish].

42. Stankiewicz A, Jamsheer-Bratkowska M, Maziarka D, Skotak K. Health risk assessment standards of cyanobacteria bloom occurrence in bathing sites. Med Srod 2011;14(1):85-92, 7 ref. [in Polish].
43. Stojek NM, Dutkiewicz J. Co-existence of Legionella and other Gram-negative bacteria in potable water from various rural and urban sources. Ann Agric Environ Med 2011;18(2):330-4, 22 ref.

44. Struciński P, Piskorska-Pliszczyńska J, Góralczyk K, Warenik-Bany M, Maszewski S, Czaja K, et al. Dioxins and food safety. Rocz Panstw Zakl Hig 2011;62(1): 3-17, 70 ref. [in Polish].

45. Strumylaite L. Cancer risk in relation to exposure to trace elements. Med Srod 2011;14(1):7-12, 64 ref.

46. Świąder K, Waszkiewicz-Robak B, Świderski F. Sweeteners - benefits and risks. Probl Hig Epidemiol 2011;92(3):392-6, 35 ref. [in Polish].

47. Wawrzeńczyk-Zdżyłowska A, Zawieska WM. Problems of sustainable development in a vibroacoustic analysis of the work environment. Bezpiecz Pr 2011;(12): 10-3, 11 ref. [in Polish].

48. Wawrzyniak A, Hamułka J. Main sources of daily nitrite and nitrate intake in young women. Probl Hig Epidemiol 2011;92(3):629-31, 7 ref. [in Polish].

49. Wojcieszyńska D, Guzik U, Hupert-Kocurek K, Marszałek J. Biochemical and physiological effects of phenols on human health. Med Srod 2011;14(1): 105-11, 30 ref. [in Polish].

50. Wójcik-Fatla A, Zając V, Knap JP, Dutkiewicz J. Hantavirus RNA not detected in Ixodes ricinus ticks. Ann Agric Environ Med 2011;18(2):446-7, 13 ref.

51. Żakowska-Biemans S. Food safety as a factor determining consumers' behavior on the food market. Probl Hig Epidemiol 2011;92(3):621-4, 12 ref. [in Polish].

This work is available in Open Access model and licensed under a Creative Commons Attribution-NonCommercial 3.0 Poland License - http://creativecommons.org/ licenses/by-nc/3.0/pl/deed.en. 